Mehmet TAŞ*

\author{
ULUSLARARASI EĞİTIM VE TARİH \\ ARAŞTIRMALARI DERGISI \\ (ETA JOURNAL) \\ INTERNATIONAL JOURNAL OF EDUCATION AND \\ HISTORY RESEARCH
}

Yıl: 4, Sayı: 1, Ocak 2022, s. 24-67.

\title{
18.YÜZYIL OSMANLI DONANMASI İÇİN HAM DEMİR TEMINİ**
}

\section{ÖZET}

Ham demir ve bu demirden imal edilen malzemeler, savaş gemilerinin inşasında önemli yer tutmaktadır. Demirin dayanıklı olması ve erişilebilirliğinin yüksek olması onu tersaneler açısından vazgeçilmez bir ihtiyacı haline getirmiştir. Demirin binlerce yıl öncesinden beri insanoğlu tarafindan bilinip işleniyor olması bu alanda uzmanlaşmanın yaygınlık kazanmasını sağlamıştır. Demiri işleyen demirciler demire duyulan ihtiyaca paralel olarak tersanelerin nitelikli iş gücü arasındaki yerlerini almıştır.

Ham demiri ayrı ayrı kazalardan toplayarak tersanelerde kullanıma hazır hale getirmek ciddi bir organizasyonu gerekli kılmaktadır. İşin; hammadde, emek, nakliyat, bütçe, personel ve dağıtım gibi unsurlarını planlayarak birbirini tamamlayan ve devamlı çalışan bir sistem kurmak lazımdır. Bu sistemin denetim mekanizmasını oluşturmak ve yasal alt yapısını meydana getirmek aynı derecede önemli olan hususlardır. Bu konuların üstesinden gelebilmek ise ciddi bir organizasyon bilgisi ve becerisi gerektirir.

Osmanlı Devleti'nde kalyondan şayka türü gemilere varıncaya kadar ham demir, az ya da çok kullanıyordu. Hatta 18. yüzyıl öncesi kadırga ve çektiri türü gemilerde de kullanılmaktaydı. Bu gemilerde kullanılan ham demirin temin edildiği kazalar genelde Balkan coğrafyasında yer almaktadır. Burada bulunan; Samakov, Filipe, Sofya, Tatarpazarı ve Demirhisar gibi kazalar ham demir üretimiyle ön plana çıkmışlardır. Devlet bu kazalardaki ahaliden talep ettiği ham demiri, genelde ocaklık usulü ile toplamakta ve kara yolu vasıtasıyla Varna, Selanik, Kavala ve Tekirdağı gibi iskelelere taşımaktadır. Daha sonra ise gemilerle bu demiri, İstanbul'da yer alan Tersane-i Âmire'de depolamaktadır. Burada depolanan demir ise gerek İstanbul'daki Tersane-i Âmire'de inşa edilen gemiler için gerekse İstanbul dışında inşa edilen gemiler için sarf edilmekteydi.

18. yüzyılda kalyon teknolojisine geçiş, diğer gemi inşa ve donatım malzemelerinde olduğu gibi ham demire olan ihtiyacı da artırmıştır. Kalyonların klasik Osmanlı savaş gemilerine kıyasla daha büyük olması onların küçük tonajlı diğer gemilere kıyasla daha fazla ham demir tüketmesine neden olmuştur. $\mathrm{Bu}$ ise

\footnotetext{
" Dr., Öğretmen, Millî Eğitim Bakanlığı, Hatay İl Milli Eğitim Müdürlüğü, Dörtyol Fen Lisesi, mehmettas@msn.com.

*** Bu makale, "18. Yüzyılda Osmanlı Donanmasında Yelken ve Yelken Bezi” isimli basılmamış doktora tezinden yararlanılarak hazırlanmıştır.
} 
önceki yüzyıllardan beri devlete ham demir temin eden kazaların yükünü ağırlaştırmıştır. Olumsuz iktisadi koşulların da etkisiyle bu durum bazen ham demir konusunda ahalinin şikâyette bulunmasına neden olmuştur.

Osmanlı donanmasının inşa ve donatımıyla ilgili çalışmalar literatürde donanmanın faaliyetlerini konu alan çalışmalara kıyasla daha az yer tutar. Bu ise meselenin bütün yönleriyle anlaşılmasını güçleştirir. Donanmaların başarısında onların yönetimi kadar onu inşa eden aklın mühendislik bilgisi de önemli yer tutar. Donanma gemilerinin farklı iklimlerin hüküm sürdüğü çeşitli denizlerde görev yaptığı düşünülecek olursa bu husus önemli bir ayrıntıdır. Bu çalı̧̧mada, bu ayrıntının daha iyi anlaşılması amaçlanmıştır.

Anahtar Kelimeler: Ham Demir, Osmanlı Donanması, Kalyon, 18. Yüzyıl, Tersane-i Âmire.

\section{CRUDE IRON SUPPLY FOR 18TH CENTURY OTTOMAN NAVY}

Crude iron and the materials made of this iron have an important place in the construction of warships. The strength and accessibility of iron has made it an indispensable need for shipyards. The fact that iron has been known and processed by human beings since thousands of years has enabled the specialization in this area to become widespread. The blacksmiths who processed the iron took their place among the qualified workforce of the shipyards in line with the need for iron.

Collecting crude iron from individual accidents and making them ready for use in shipyards requires a serious organization. It is necessary to establish a system that complements each other and works continuously by planning the elements of the business such as crude materials, labor, transportation, budget, personnel and distribution. It is equally important to establish the audit mechanism of this system and to establish its legal infrastructure. To overcome these issues requires serious organizational knowledge and skills.

Accidents in which the crude iron was supplied in the Ottoman State are generally located in the Balkan geography. Accidents such as Samakov, Filipe, Sofia, Tatarpazarı and Demirhisar have come to the fore with crude iron production. The state usually collects the crude iron from the people in these accidents by quarrying and transports it to the piers such as Varna, Thessaloniki and Kavala by road. Later on, he stores this iron in ships at the Tersane-i Âmire in Istanbul. The iron stored here is used for ships built both in Istanbul and outside Istanbul.

The transition to galleon technology in the 18th century increased the need for raw iron. The larger galleons compared to the classical Ottoman warships caused them to consume more crude iron. This has increased the burden of accidents supplying the state with crude iron since the previous centuries. Due to the negative economic conditions, this situation sometimes caused the people to complain about the crude iron.

Studies on the construction and equipment of the Ottoman navy occupy less space in the literature compared to the studies on the activities of the navy. This makes it difficult to understand the issue in all its aspects. The engineering knowledge of the mind that built it is as important as their management in the success of the navy. Considering that navy ships operate in various seas with different climates, this is an important detail. In this study, it is aimed to better understand this detail.

Keywords: Crude Iron, Ottoman Navy, Galleon, 18th Century. Tersane-i Âmire.

\section{GíRiş}

Demir, dayanıklılığı ve erişilebilirliği dolayısıyla, gemilerde sıkça kullanılan bir inşa ve donatım malzemesidir. İlk defa, nerede ve ne zaman ortaya çıktığ tam olarak bilinemese de demir cevherinin ve yeterli miktarda odunun bulunduğu birçok yerde demir üretiminin geliştiği bilinmektedir. Özelliği itibarıyla demir madeni, doğada oksit, sülfür, karbonat ve bileşikleri halinde bulunmaktadır. Yapılan bir dizi fiziksel ve kimyasal işlemin ardından, 1500 santigrat dereceyi bulan sıcaklıkta bu maddeler eriyerek bilinen demir madenine vücut vermektedir. İnsanlar, Orta Çağ ve Yeni Çağ'da demir elde etmek 
için günümüze kıyasla daha basit bazı yöntemler geliştirmişti. Buna göre göre balçı, mıcır taşı ve birleşik taşlardan yapılan kuyular, firın amacıyla kullanılmaktadır. Bu kuyular fazla çukur ve derin kuyular değildi. Fırın işlevi gören bu kuyularda, demir cevheri yıkandıktan ve kavrulduktan sonra odun kömürü ile eritiliyordu. Odun kömürünün yaydığı 1sıyı artırmak içinse insan gücüyle ya da su gücüyle çalışan körükler kullanılmaktayd $1^{1}$.

Osmanlı donanmasının inşa edildiği çeşitli tersanelerde, "ahen-i ham" olarak isimlendirilen ham demire yoğun biçimde ihtiyaç duyulmaktaydı. Bu ihtiyacın kaynağında ise ham demirin çivi, kolye ${ }^{2}$, çapa ve lenger gibi malzemelerin inşasında kullanılması ile gemilerde kullanılan birçok malzemenin ham demirden imal edilmesi gerçeği yatmaktayd ${ }^{3}$. Bu gerçek kendisini kalyon teknolojisine kesin olarak geçildiği 18 . yüzyılda, önceki yüzyıllarla kıyaslanmayacak biçimde devlet adamları ve ahali nezdinde hissettirmeye başlamıştır. Kalyonların; kadırga, kalyete, şayka ve karamürsel gibi klasik Osmanlı savaş gemilerine kıyasla daha büyük ve daha geniş gemiler olması, bunların inşasında daha fazla ham demir kullanılmasını gerektirmekteydi ${ }^{4}$.

Kalyonlarda ham demirin kullanıldığı malzemelerin başında çivi, kolye, çapa ya da lenger $^{5}$, gomina ${ }^{6}$, top parliyesi, hınzır yayı, lombar kancası ${ }^{7}$, lombar halkası, kurna ${ }^{8}$ halkası, palanga halkası ${ }^{9}$, kapak halkası ve top arabası tamiri gibi malzeme ve işler girmekteydi ${ }^{10}$. Bunları imal etmek için, ülke içinde toplanan ham demirin dişında farklı demir türleri de kullanılmaktayd1. Örneğin 1772/1773 yılında "Frengi-i kebir timuru" adıyla bilinen bir tür demir daha kullanılmaktaydı. Bu demir muhtemelen Avrupa donanmalarından esinlenilerek kullanılmaya başlanmıştı. Aynı yıl "kebir frengi gomina" ve "frengi-i cedid gomina" gibi yine Avrupa menşeili gominaların kullanılmakta oluşu,

\footnotetext{
${ }^{1}$ Kutlay Oral, "Demir Cevherinin Metalurjisinin Doğuşu ve Tekamülü”, Bilimsel Madencilik Dergisi, Sayı 6, Y11 1970, s. 39.

${ }^{2}$ Tersane-i Âmire'de inşa olunan bir adet üç ambarlı kalyon ile bir adet 54 ziraa $(40,9$ m.) uzunluğunda başka bir kalyonun inşasında mismar ve kolyeye ihtiyaç duyulduğu ancak bunları üretmeye yetecek miktarda ham demirin Mahzen-i Sürbte bulunmadığ ile ilgili 10 Rebiyülevvel 1217 (11 Temmuz 1802) tarihli arz için Başbakanlık Osmanlı Arşivi Daire Başkanlığı, Cevdet Bahriye Tasnifi, (BOA.C.BH.) 104.5006.1.1.

${ }^{3}$ Yusuf Alperen Aydın, Sultanın Kalyonları, Küre Yayınları, İstanbul 2011, s. 281.

${ }^{4}$ Kadırgalar kalyondan önceki dönemde Osmanlı donanmasının ana muharip gemisiydi. Hafif oluşu nehir ağzı ve göl gibi sı̆̆ sulara yanaşma imkânı sağlarken hem kürek hem de yelkeni aynı anda kullanabilmesi onu düşman gemilerini takip ve baskınlardan sonra düşman gemilerinden kaçış için büyük bir avantaj sağlıyordu. Kalyona geçiş tartışmalarının yaşandığı 17.yüzyılda kadırga inşası devletin askeri ihtiyaçlarına paralel şekilde devam etmiştir.3 Safer 1077 (5 Ağustos 1666) tarihinde Tersane emini Süleyman Tersane-i Âmirede inşa olunacak kadırgaların mühimmatı için ziyade ham demire ihtiyaç olduğunu bildirmiştir. (bk. Başbakanlık Osmanlı Arşivi Daire Başkanlığı, Maliyeden Müdevver Defterler -BOA.MAD.d.- 9848.22)

${ }^{5}$ Lenger demir anlamına gelen bir terimdir. Gemilerden suya atılarak açık sularda onların denizin akıntısına karşı sabit durmasını sağlarlar. (Metin Karayazgan, Denizci Sözlüğü, Karşıyaka 1981, s. 86.)

${ }^{6}$ Gomina gemi demirinin zinciridir. (bk. Metin Karayazgan, age. , s. 48.)

${ }^{7}$ Lombar, geminin bordalarına sıra halinde açılmış olan ve top namlularının geçmesine yarayan dört köşeli deliklerdir. (bk. Metin Karayazgan, age., s. 87.)

${ }^{8}$ Kurna, üç katlı balık ağının en dıştaki geniş katıdır. (bk. Metin Karayazgan, age. , s. 83.)

${ }^{9}$ Palanga, iki makaradan geçirilmiş bir halattan oluşan ve ağır cisimleri kolayca kaldırmaya yarayan alettir. (bk. Metin Karayazgan, age. , s. 101.)

${ }^{10}$ BOA.MAD.d.3014.73
}

\section{ULUSLARARASI EĞİTIM VE TARİH ARAŞTIRMALARI DERGİSI} (ETA JOURNAL) 
Osmanlı donanmasının 1770'den sonra içine girdiği yenileşme temayülünden kaynaklanmaktadır $^{11}$. Bunun dışında Tuna donanmasında görev yapan çete kayıkları ve şaykaların inşasında kullanılan ve "tırnaklı demir" olarak isimlendirilen bir tür demir daha $\operatorname{vard}^{12}$. Bu demir, lengerlerle birlikte kullanılarak geminin dalga ya da akıntıya karşı su yüzeyinde sabit kalmasını sağlıyordu ${ }^{13}$. Kâtip Çelebi, Tuhfetü'l-Kibar fi Esfari'lBihar isimli eserinde, kendi dönemindeki gemilerde kullanılan çengelli demirden bahsetmektedir. Kâtip Çelebi, bu demirin özellikleri hakkında bilgi vermese de bir mavna ve baştardanın 12 kantar $(676,8 \mathrm{~kg})$ ağırlığında 4 adet çengelli demire ihtiyaç duyduğunu bildirmektedir ${ }^{14}$. Kalyonların ana silahı olan topların demirden imal edilmiş olduğu düşünülecek olursa, bu durumda demirin kalyonlar için gerekli olan savaş yeteneği ve savaş alanında asli savaş fonksiyonlarını icra edebilmeleri için ihtiyaç duydukları ateş gücü açısından ne kadar önemli bir malzeme olduğu kendiliğinden anlaşılacaktır. Bu durum demirin istikrarlı bir biçimde temin ve işlenmesi için kendine özgün bir teşkilatlanma ihtiyacını da beraberinde getirmiştir.

Osmanlı donanmasında, gemilerin donatımında kullanılan demirlerin, miktar olarak vukıyye ve kantar gibi ağırlık birimleriyle ifade edilmesine karşılık gemi uzunluklarının ziraa gibi ölçü birimleriyle ifade edildiği görülmektedir.Bu çalışmada günümüzde yaygın biçimde kabul edildiği üzere, 1 vukıyye 1,282 kg, 1 kantar 56,3 $\mathrm{kg} 1$ ziraa ise 75,7 cm olarak kabul edilmiştir. Ancak bu ölçüler tarih boyunca her yerde aynı değeri ifade etmiyordu. Örneğin ziraa günümüzde her ne kadar $75,7 \mathrm{~cm}$ ifade etse de tek bir ziraa yoktu. İslam dünyasının farklı coğrafyalarında farklı ziraa ölçüleri kullanılmaktaydı. Ziraaü'l- amel 66,5 cm, ziraaü'l-amme 54,04 cm,ziraaü'l-belediye 58,26 cm, ve ziraaü'lberid $49,8 \mathrm{~cm} \mathrm{idi}{ }^{15}$. Ağırlık ölçüsü birimlerinden olan kantar ise hem Anadolu Selçuklularında hem de Osmanlılarda her biri 176 dirhem olan 100 lodraya eşitti. Bugüne kadar ağırlığı fazla değişmeden $56,4 \mathrm{~kg}$ olarak gelmişti ${ }^{16}$. Okka ya da vukıyye her biri 3,207 gramlık 400 dirheme eşit olan bir Osmanlı ağırlık birimi olup 1,282 kg ağırlığa tekabül etmekteydi ${ }^{17}$.

\section{Ham Demirin Gemilerde Önemi}

Ham demir, kullanıldığ 1 gemi türleri açısından başta kalyon, kadırga ${ }^{18}$,şalopa ${ }^{19}$, işkampaviya ${ }^{20}$, çekeleve, sandal, filika ${ }^{21}$ olmak üzere bütün gemilerde az ya da çok ama

\footnotetext{
${ }^{11}$ BOA.MAD.d.3014.73

12 Cebehane-i Amire mevcudundan dörder tırnaklı demirin Tuna donanmasında kullanılmak üzere Silistre'ye nakledilmesi hakkındaki 5 Recep 1205 (10 Mart 1791) tarihli arz için bk. BOA.C.BH.41.1933.1.1.

${ }^{13}$ Tırnak, dibe tutunmayı sağlayan admiralti demirinin kollarının sonundaki yassı ve uçları sivri bölümüdür. (bk. Metin Karayazgan, age. , s. 122.)

${ }^{14}$ Katip Çelebi, Tufetü'l- Kibar fi Esfari'l-Bihar, Hazırlayan: Orhan Şaik Gökyay, Kervan Kitapçılık, Cilt 2., İstanbul 1980, s. 239.

${ }^{15}$ Walter Hınz, İslam'da Ölçü Sistemleri, Çeviren: Acer Sevim, Edebiyat Fakültesi Basımevi, İstanbul, 1990 , s.68/69.

${ }^{16}$ Walter Hinz, age. , s. 33.

17 Walter Hinz, age. , s. 30.

18 Tersane Emini Süleyman isimli bir kamu görevlisi, mühürlü tezkire göndererek, 1077 (1666/1667) senesinde Tersane-i Amire'de inşa olunacak donanma kadırgaları için 2,000 (112,640 kg) kantar ham
} 
mutlaka belli bir oranda kullanılmaktayd1. Demirin kullanıldığı malzemelerin başında yukarıda kısmen ifade edildiği üzere lenger, top arabaları, top halkaları, top kancaları, araba takımları, cıvata, çivi, sütun çemberleri ${ }^{22}$ gomina $^{23}$, halka, lombar kapağı kancası, dümen iğnecikleri ${ }^{24}$ ve su mancanalarının ${ }^{25}$ çemberleri gelmekteydi ${ }^{26}$.

18.yüzyıl temel alındığında donanmanın asıl savaş gemisi kalyonlardı ve kalyonlarda demirden mamul birçok araç ve malzeme kullanılmaktaydı. Bunları Mahzeni Sürb'te bulunan ve çeşm olarak isimlendirilen depolarda tutulan malzemelerden anlamak mümkündür. Bu malzemelerin bir kısmı Tersane-i Âmire'ye İstanbul dışından gelen demirden imal edilmişken bir kısmı da Tophane-i Âmire ve Cebehane-i Âmire gibi kurumlardan buraya gönderilmişlerdir. 18. yüzyılda ham demirin donanmada yaygın kullanım sahasını göstermesi açısından 13. çeşmde yer alan başlıca demir eşyalar aşağıda verilmiştir $^{27}$;

1. Müstamel âhen çember sütun (361 vukiyye/462,8 kg)

2. Müstamel kalyon lengeri (3 adet)

3. Demir halka(12 vukıyyesi küçük ve 12 vukıyyesi büyük olmak üzere toplam 24 vukıyye $/ 30,7 \mathrm{~kg}$ )

4. Demirden yapılmış kırık zift kevgiri (2 adet)

5. Çanaklık çember demiri (2 adet)

6. Büyük c1vata demiri (2 vukıyye $/ 2,5 \mathrm{~kg}$ )

7. Demirden yangın tulumbası kancası (1 adet)

8. Çivi (353 vukıyye $/ 452,5 \mathrm{~kg})$

9. Demirden lombar kancas1 (5 adet)

10. Demirden yay çarmı (2 adet)

11. Civatalı demir halka (10 adet)

12. Makarası ile demir kanca (4 adet)

demirin lazım olduğunu bildirerek bunların geçerli olan narh fiyatı üzerinden Samakov’dan satın alınmasını arz etmişti. 3 Safer 1077 (5 Ağustos 1666) tarihli hüküm için bk.MAD.d.9848.63.

${ }^{19}$ Şalopa iki direkli ve yelkenli bir savaş gemisidir. Önceki yüzyıllarda olduğu gibi 18.yüzyılda da Osmanlı donanmasında varlığını sürdüren bu gemiler diğer gemiler gibi demirden mamul eşyalar kullanmaktaydı. Rodos adasında inşası emredilen şalopalar için 1203 (1788/1789) yılında 10 adet demire ihtiyaç duyulmuş ve bu miktar demirin Rusçuk cephanesi mevcudundan verilmesi emredilmişti. Konuyla ilgili ferman için bk.MAD.d.104.13.121.

${ }^{20}$ BOA.MAD.d.3014.65.

${ }^{21}$ BOA.MAD.d.10429.73.

${ }^{22}$ BOA.MAD.d.10413.111.

${ }^{23}$ Gomina, gemi demirinin zinciridir. (bk. Metin Karayazgan, age.,s.48.)

24 İ̆nnecik, dümeni, kıç bodoslamaya bağlayan dişli ve madeni menteşedir. (bk. Metin Karayazgan.age.,s.58.). 1211 (1796/1797) yılında yayınlanan bir fermanda donanma kalyonlarının dümenlerine konulan iğneciklerin aslında demirden imal ettirilegeldiği ancak birkaç seneden beri taşra ve Tersane-i Âmire'de inşa olunan kalyonlara bakır kaplanması irade buyurulduğu için bakır kaplanacak iğneciklerin tunçtan imal edilmesi lazım geldiği ifade edilmekteydi. Konuyla ilgili ferman için bk. BOA.MAD.d.10429.73.

${ }^{25}$ Mancana, gemilerde içine su konulan büyük yassı fiçılardır. (bk. Metin Karayazgan. age., s .90.)

26 Aslan-1 Bahri isimli kalyonun malzemeleri arasında yer alan top halkaları, araba takımları, cıvata ve çiviler demirden imal edilmişti. Bunun için 8,000 kantar $(450,560 \mathrm{~kg})$ ham demire ihtiyaç duyulmuştu. Konuyla ilgili Tersane emini tarafindan gönderilen arz yazısının içeriği hakkında bk.MAD.d.104.60.

${ }^{27}$ Konuyla ilgili ayrıntılı malzeme listesi için bk. BOA.MAD.d.3014.83.

\section{ULUSLARARASI EĞİTIIM VE TARİH ARAŞTIRMALARI DERGİSI \\ (ETA JOURNAL)}

INTERNATIONAL JOURNAL OF EDUCATION AND HISTORY RESEARCH

Yıl: 4, Sayı: 1, Ocak 2022, s.24-67. 


\section{$\underline{\text { Mehmet TAS }}$}

13. Demir top (3 adet)

15. çeşmde yer alan demir eşyalar ise şunlard1;

1. Demirden firaşkon ${ }^{28}$ kancası (7 adet)

2. Demirden yapılmış halkalı cıvata (5 adet)

3. Demirden yapılmış kalyon iskelesi kolu (5 adet)

4. Demirden ray kancası (37 adet)

5. $\quad$ Demir top ( 2 adet)

6. $\quad$ Sade demir ziban (2 adet)

7. Çağlayan havuzu için demir kapak (2 adet)

Burada bulunan demir eşyaların tamamı, Tersane-i Âmire'de ya da Tophane ve Cebehane-i Âmire gibi kamu kurumlarında üretilmeyip bir kısmı serbest piyasa koşullarına göre faaliyet gösteren demirci esnafına yaptırılmıştı. Örneğin 1772/1773 yılında Tersane Emini el-Hac Yusuf Efendi zamanında, 910 kantar (51,331 kg.) ağırlığında çengel demiri, Galata demircilerine imal ettirilmişti ${ }^{29}$. Demir, donanmanın da işlevsel yönden bir parçasını oluşturduğu Osmanlı ordusunda, yaygın bir şekilde kullanılmaktaydı. Sadece Tersane-i Amire değil Tophane-i Amire ve Cebehane-i Amire gibi kurumsal yapılar da demiri yaygın olarak kullanmaktaydı. Ordunun ana mühimmat kaynağı olan Cebehane-i Amire'de üretilen kılıç, hançer, balta ve kanca gibi silahların hammaddesi demirdi ${ }^{30}$.

Demirin, Osmanlı donanması için taşıdığı öneme binaen, eksik olması ya da inşa edildiği gemiye uygun olmaması bir geminin denize indirilmesine engel olabilmekteydi. Böyle bir örnek 1708/1709 yılında yaşanmıştı. Bu tarihte Sinop'ta inşa olunan 3 adet kalyon denize indirilecek derecede inşası tamamlandığı halde daha önce gelen demirlerin 60 ziraa $(45.4 \mathrm{~m})$ uzunluğundaki bir kalyonda kullanılmaya uygun olmadığının anlaş1lması üzerine kaptanlar ve ustalar bir araya gelerek 2 adet demir gelmedikçe kalyonların İstanbul'a gelemeyeceğini bildirmişlerdi. Bunun üzerine Tersane-i Âmire'de bulunan büyük kalyon demirlerinden 2 adet demirin gönderilmesine karar verilmişti ${ }^{31}$.

Demir, yalnız Tersane-i Âmire'de inşa edilen asıl donanma gemilerinde değil "ümera-yi derya" gemilerinde de kullanılmaktaydı. Ümera beyleri olarak isimlendirilen kişiler kaptan paşa eyaletinin sancak beyleriydi ve bunlar sefer zamanı geldiğinde gemiler donatıp sefere iştirak etmekle yükümlüydü. Barış zamanında ise bulundukları bölgede korsanlarla mücadele ederek emniyet ve güvenliği sağlamakla mükelleftiler. $\mathrm{Bu}$ yükümlülüğün ifası bağlamında, kaptan olmaları dolayısıyla Tersane-i Âmire tarafindan kendilerine verilen mühimmatlar arasında, demir ve demirden mamul eşyalar da bulunmaktaydı. Haziran/Temmuz 1714 yılında Eğriboz adasının muhafazası için 4 adet

\footnotetext{
${ }^{28}$ Firaşkon, üçer dilli iki makaradan oluşan palangadır. (bk. Metin Karayazgan, age. , s. 42.)

${ }^{29}$ Bahse konu olan 910 kantar demir, 250 parça çengel demirinin imali için kullanılmıştır. Bu demirler ise 1772/1773 yılında inşası emredilen 40 adet firkate ve 10 adet işkampoyenin inşasında kullanılacaktır. 25 Muharrem 1186 (28 Nisan 1772) tarihli ferman için bk. BOA.MAD.d.3014.65.

${ }^{30}$ Cebehane-i Âmire'de 1165 senesi içinde yaptırılan 300 adet yangın baltası ve 300 adet kancanın imali için 577 vukıyye (739 kg) demir kullanılmıştı. (bk.BOA.MAD.d.10354.13.)

${ }^{31}$ Konuyla ilgili 18 Safer 1120 (9 Mayıs 1708) tarihli ferman için bk.BOA.MAD.d.2489.24.
} 
firkate görevlendirildiğinde bunların kaptanlarına verilen lenger, top ve ham demir şu şekildeydi ${ }^{32}$;

\begin{tabular}{|l|c|c|c|}
\hline Firkate ismi & Lenger (Adet) & Demir (Adet) & Tunç Top (Adet) \\
\hline Kızılhisari Mustafa Kaptan & 16 & 8 & 2 \\
\hline El-Hac Hasan Kaptan & 16 & 8 & 2 \\
\hline El-Hac Ahmet Kaptan & 16 & 8 & 2 \\
\hline Galatalı Hasan Kaptan & 16 & 8 & 8 \\
\hline Yekûn & 64 & 32 & 2 \\
\hline
\end{tabular}

Tablo 1. Bazı Firkatelere Verilmiş Olan Ham Demir Miktarı.

Lenger, üretimi için demire en çok ihtiyaç duyan malzemelerin başında gelmekteydi. Lenger, geminin açık sularda durup bekleme yapabilmesi için ya da firtınalı olumsuz hava koşullarında belli bir noktada sabit durmasının sağlanması için varlığına en çok ihtiyaç duyulan malzemeydi. Suya atıldı̆̆ı yerde, su altı yüzeyini daha iyi tutması için çengel demirinden imal edilmekteydi. Kalyonlar için imal edildiği yer ise genellikle Tersane-i Amire içinde yer alan Lengerhane idi ${ }^{33}$. Pergendi, kalyete, şalopa vd. gemilerin lengerleri de burada imal edilmekle birlikte, ihtiyaç halinde Galata bulunan lengerci esnafina da imal ettirilmekteydi. Lengerler, büyük, orta ve küçük olmak üzere 3 sınıfa ayrilmaktaydi ${ }^{34}$.

Lenger, varlık olarak kalyondan çete kayıklarına varıncaya kadar her tür Osmanlı gemisinde kullanılmaktayd ${ }^{35}$. Ama 18.yüzyıl söz konusu olduğunda en çok kullanılan gemi türü hiç şüphesiz ki kalyonlardı. $\mathrm{Bu}$ yüzyılda donanmanın önde gelen kalyonlarından olan Mülk-i Bahri kalyonu her biri 33 kantar $(1858 \mathrm{~kg})$ ağırlı̆̆ında 5 adet lengere sahipti. Diğer önemli kalyonlardan olan, Servi Bağçeli kalyonu her biri 29 kantar (1633 kg) ağırlığında 5 adet lengere ve Şeşpa-yi Bahri kalyonu her biri 13 kantar (732 kg) ağırlığında yine 5 adet lengere sahipti. Başka bir kalyon olan, Aslan Başlı kalyonu ise diğer kalyonların lengerleriyle mütenasip şekilde, her biri 11 kantar (619 kg) ağırlı̆̆ında 4 adet adet lengere sahipti. Donanmanın büyük kalyonları arasında geçen, Çifte Aslan Kıçlı kalyon da her biri 14 kantar $(788 \mathrm{~kg})$ ağırlığında 5 adet lengere sahipti. Gemilerin ağırlığına ve amaca uygunluğuna göre lengerlerin ağırlığı ve sayısı da değişiyordu. Ama donanmanın en gözde kalyonlarının kullandığı lenger sayıs1-5-6 lengerden ibaretti.

\footnotetext{
32 BOA.MAD.d.3133.37.

33 “...iktiza iden demirlerin imal ve ikmali vakte muhtaç olup Lengerhane'de kalyon demirleri imal olunmak hasebiyle zikrolunan pergendi lengerleri... (22 Ramazan 1185/29 Aralik 1771)" (bk. BOA.MAD.d.10388.70.)

34 “....donanma-yı hümayun kalyonları için hîn-i iktizada, kebir ve vasat ve sağir her nev'inden mevcut bulunmak üzere...(27 Safer 1120/18 Mayıs 1708) (bk.BOA.MAD.d.2489.25.)

${ }^{35}$ BOA.MAD.d.10391.90.
}

\section{ULUSLARARASI EĞİTIIM VE TARİH ARAŞTIRMALARI DERGİSİ \\ (ETA JOURNAL)}

INTERNATIONAL JOURNAL OF EDUCATION AND HISTORY RESEARCH

Yıl: 4, Sayı: 1, Ocak 2022, s.24-67. 
1733/1734 y1lında 33 adet kalyona 198 adet lenger lazım olduğunda bu lengerlerin ağırlığ 0,6 kantar $(33,7 \mathrm{~kg})$ ile 10 kantar $(563 \mathrm{~kg})$ arasında değişiyordu. Bu tarihte adı geçen 33 kalyon için en çok talep edilen lengerin ağırlığ 1,8 kantar $(101,3 \mathrm{~kg}) \mathrm{kadard}_{1}{ }^{36}$.

Türleri açısından ham demir, temin edildiği yere bakılarak Samakov demiri ve İne ada demiri olarak ikiye ayrılmaktaydı. Sofya, Samakov, Tatarpazarı, Filipe ve Dubniçe gibi kazalardan toplanan demire Samakov demiri adı verilirken Kurklareli'nde bulunan İneada'dan temin edilen demire İneada demiri denilmekteydi ${ }^{37}$. Ham demir temin biçimine göre ise ocaklık demiri ya da tüccar demiri biçiminde ikiye ayrılmaktaydı. Ocaklık demiri, avarız ve tekâlif gibi vergi yükümlüsü bazı kazaların ahalisi tarafından bu vergilere karşılık olarak devletçe belirlenmiş bir fiyat üzerinden üretilmiş olan demirdi. Tüccar demiri ise ocaklık demirin yeterli olmadığ durumlarda ya da acil ihtiyaçlar nedeniyle serbest piyasa koşullarında faaliyet gösteren yerli ve yabancı tüccar ile esnaftan satın alınan demirdi ${ }^{38}$.

Kalyon inşasında, demirden mamul eşyalar miktar açısından olduğu kadar ücret açısından de önemli bir maliyet unsuru oluşturmaktaydı. Demircilere ödenen ücretler de bu malzemelerin ücretine eklendiği zaman bunlar hayli kabarık bir yekûna ulaşmaktaydı. Kalyon inşası için Tersane eminleri tarafindan tutulan kalyon defterlerinden bunu anlamak mümkündür. Örneğin 18. yüzyılda tutulduğu anlaşılan 3 adet yeni kalyon ile 10 adet eski kalyona lazım gelen demirden mamul eşyalar ile bunların ücreti dikkate alındığında, keresteden sonra varlığı harcama kalemleri arasında en fazla yer tutan malzeme demirdi. Bahse konu kalyonlarda demirden mamul ya da inşasında demir kullanılan bazı malzemeler ile bunların ücreti aşağıda verilmiştir ${ }^{39}$;

1. Lengerler $(633,600$ akçe $)$

2. Demirci ücreti $(247,000$ akçe $)$

3. Fıçı $(81,000$ akçe)

4. Varil $(28,800$ akçe $)$

5. Tulumba $(18,000$ akçe $)$

6. Lofça çivisi $(11,400$ akçe)

7. Zift kazanı (10,500 akçe)

8. Zagra Çivisi (3,000 akçe)

Keresteden mamul malzemelerin listeye dahil edilmediği bu listedeki malzemeler, bir kalyonun inşasında ve kalafatlanmasında kullanılan ana malzemeler olup bu veriler dikkate alınacak olursa demirden mamul eşyaların ücreti 1,036,000 akçeye ulaşmaktadır. Listede ismi geçen malzemelerin toplam ücreti ise 1,704.000 akçe olup, demir ve demirden mamul eşyalar, bunun yaklaşık olarak \%60,7'ni oluşturmaktadır.

\footnotetext{
${ }^{36}$ Kalyonların isim ve sayıları ile bunlara verilen lengerler için bk.BOA.MAD.d.10321.53.

${ }^{37}$ Beher vukıyyesi 11'er akçeden bir miktar demir, 5 Şevval 1201 (21 Temmuz 1787) yılında İneada demiri adıyla satın alınmıştı.(bk.BOA.MAD.d.10412.119.)

38 “...Tersane-i Âmire'ye gelen demir gelmezden mukaddem bezirgandan alınan demir..." (bk.BOA.MAD.d.2489.27.)

39 Tersane emininden gelen tarihsiz bir kalyon defteri için bk. BOA.D.2709.1.0.1.
} 
Kalyon inşasında kullanılan çivi ve cıvatalar, 1792/1793 yılı itibarıyla tamamen demirden imal edilmekteydi. Demir çivi ve cıvatalar, geminin kerestelerini bir arada tutarak geminin sağlamlığı için önemli bir işlevi yerine getirmekteydi. Ancak bu durum bazı olumsuzlukları beraberinde getirebilmekteydi. Örneğin çivi ve cıvatalar demirden yapılmış olduğu için geminin ağırlığını artırıyor bu ise gemilerin manevra yeteneğini azaltıyordu. Ayrıca demir çiviler, nem ve sıcaklığın etkisiyle kolayca paslanarak üzerinde bulunduğu kerestenin çabuk çürümesine neden olmaktaydı. Bu durumla başa çıkabilmek için 18.yüzyıl sonlarına doğru kavale ${ }^{40}$ olarak isimlendirilen ahşap çivilerin imal edilerek belli aralıklarla gemilerde kullanılmasına karar verilmiştir. Bu dönemde Fransa'dan gelerek Osmanlı donanmasında görev alan Le Bron ya da Baltazar gibi Fransız mimarlar buna ön ayak olmuşlardır. Ahşap çivinin ön plana çıkmasıyla birlikte Lâpseki ve Çardak kazaları ahalisi kavalelik odun imalatıyla sorumlu tutulmaya başlanmıştır. Kavale imali için de Mekri iskelesindeki tüccar taifesinden, 30,000 adet pırnal çalısının Rodos mütesellimi Murabıtzade Hüseyin kaptan vasitasıyla 13 Ekim 1792 tarihinde satın alınması emredilmiştir ${ }^{41}$.

\section{Ham Demirin Temin Edildiği Yerler}

Donanma kalyonları için tersanelerde kullanılan ham demir, ocaklık yükümlüsü reayadan, kamu kurumlarından ve tüccar ya da esnaftan temin edilmekteydi. Ham demirin temin edildiği resmî kurumların başında ise Cebehane-i Âmire ve Tophane-i Âmire gelmekteydi. Reayadan ise daha çok ocaklık usulü ile toplanmaktayd1. Ocaklık usulüyle demirin mubayaa rejimi esaslarına göre satın alındığı yerlerin başında Samakov kazası gelmekteydi. Samakov'un dışında Tatarpazarı, Dobnice, Sofya, Filibe, Atrebolu İznebol, İzladi ve Eğridere kazalarından da demir temin edilmekteydi. Ham demir bu kazalardaki demir ocaklarında hazırlanmaktayd $1^{42}$.

\section{1. Ham Demirin Temini İçin Görevli Kılınmış Kamu Kurumları}

Osmanlı Devleti'nde kamu kurumları, işlevsel olarak birbiriyle bağlantılı ve birbirine destek verecek biçimde örgütlenmişti. Örneğin sınır boylarındaki kalelere Tersane-i Âmire'den demir, kereste ya da kumaş bez gibi malzemeler giderken buraya Cebehane-i Âmire ya da Tophane-i Âmire'den mühimmat akışını sağlayan bir sistem oluşturulmuştu. Tersane-i Âmire'de ihtiyaç duyulan toplar buraya Tophane-i Âmire'den gelirken toplarda kullanılan barut ise Baruthane-i Âmire'den gelmekteydi. Baruthane-i Âmire'de üretilen barutu kurutmak ve parlatmak için ihtiyaç duyulan bezler ise Tersane-i Âmire'den gönderilen yelken bezleri ile karşılanmaktaydı. Ham demirin temininde de bu şekilde birbiriyle iç içe geçmiş ve birbirini destekleyen bir sistem kurgulanmıştı.

\footnotetext{
${ }^{40}$ Kavale sert ağaçtan yapılan ve gemilerin su kesiminden aşağı olan kısımları için kullanılan çivilerdir. (bk. Süleyman Nutki, age., s.154.)

${ }^{41}$ Rodos mütesellimi Murabitzade Hüseyin kaptana hitaben 26 Safer 1207(13 Ekim 1792) tarihinde yazılan ve konusu Mekri iskelesinde mevcut olan pırnal ağaçlarından seçerek mutat fiyatı ile satın alacağ 30,000 adet kavalyelik pırnal ağacını gemiye yükleyerek İstanbul'a göndermesi olan hüküm için bk. BOA.C.BH.247.11461.2.1.

42 Yusuf Alperen Aydin, age. , s. 282.
} 
$\mathrm{Bu}$ bağlamda ham demirin temini konusunda görevli kılınmış kamu kurumları şunlard1;

\section{1. 1. Cebehane-i Âmire}

Cebehane-i Âmire, önceleri silah ve savaş malzemelerinin korunması için tahsis edilmiş olan bir yere verilen isimdir. Sonraları ise barut, fişek ve gülle gibi mühimmat ile bu mühimmatın bulundurulduğu yere Cebehane-i Âmire denilmiştir ${ }^{43}$. Burası, başta Tersane-i Âmire olmak üzere hem İstanbul hem de İstanbul dışındaki tersanelere farklı tarihlerde önemli miktarda ham demir göndermiştir. Örneğin Kastamonu mütesellimi elHac Ali Ağa tarafından Sinop'ta inşa olunan donanma kalyonları için, 15 Kasım 1786 tarihinde 250 kantar (14,102 kg.) ham demir Cebehane-i Âmire tarafindan gönderilmiştir. 1790/1791 yılında Tuna donanması için köprü ve şalopa inşası amacıyla demire ihtiyaç duyulduğunda bunların bizzat muayene edilerek büyük, orta ve küçük şeklinde sinıflandırıldıktan sonra Cebehane-i Âmire mevcudunda yer alan kalyon demirinden verilmesi emredilmiştir ${ }^{44}$.

\section{1. 2. Tophane-i Âmire}

Tophane-i Âmire, Osmanlı ordusu için top dökülen yer anlamına gelmektedir. Burada bulunan dökümhane, Kanuni Sultan Süleyman (1520-1566) döneminde yapılmıştır. 2 firını bulunup senede 300 top dökülmektedir. Buradaki ustaların başında, dökücü başı olarak isimlendirilen bir görevli bulunmaktadır ${ }^{45}$.

Donanma gemilerinin kullandığı lenger demirlerinin bazen burada yaptırılmış olduğuna dair kayıtlar vardır. Örneğin 1696/1697 yılında denize açılacak olan Akdeniz donanmasının lenger demirlerinin Tophane-i Âmire'de yaptırılması emredilmiş ancak bu demirlerin zamanında yetişmeyeceği anlaşılınca, İstanbul kaymakamına ve tersane eminine gerekli tedbirleri almaları için bir ferman gönderilmiştir ${ }^{46}$.

\section{2. Ocaklık Usulü ile Ham Demir Satın Alınan Kazalar}

Ocaklık usulü, sınırı önceden devletçe belirlenmiş bir tavan fiyat üzerinden devlete ait bazı mal ve hizmetlerin, belli kazalardaki ahali tarafından karşılanmasını ifade eden bir terimdir. Bu usulde, bazı kazaların ahalisi avarız ve benzeri örfi vergileri ödemek yerine devletçe talep olunan bazı mal ve hizmetleri temin etmektedir. Örneğin Samsun ahalisi kendir, Fatsa ahalisi tel, Boğhazhisarı ahalisi yelken bezi ve Kocaeli ve Biga sancaklarında yaşayan kazaların ahalisi ise kereste temin etmekteydi. Gelibolu'da bulunan Malkara, Keşan, Cisr-i Ergene ve Ezine gibi kazaların ahalisi ise donanma gemilerinde tüketilen peksimetin hammaddesi olan buğdayı ocaklık usulüyle devlete sağlamakla yükümlüydü. Osmanlı donanması inşa edildikten sonra burada görev yapan

\footnotetext{
${ }^{43}$ Mehmet Zeki Pakalın, Osmanlı Tarih Deyimleri ve Terimleri Sözlüğü, Cilt 1, 3. Baskı, Milli Eğitim Basımevi, İstanbul 1983, s. 264.

${ }^{44}$ Cebehane-i Âmire'de mevcut olan kalyon demirlerinin Tuna donanması için Silistre'ye naklettirilmesi hakkındaki 5 Recep 1205 (10 Mart 1791) tarihli ferman için bk. BOA.C.BH.41.1933.1.1.

${ }^{45}$ Mehmet Zeki Pakalın, age. , Cilt 3, s. 34.

46 İstanbul kaymakamı ve tersane eminine hitaben, 9 Şevval 1108 (1 Mayıs 1697) tarihinde gönderilen ferman için bk. BOA.MAD.d.3419.197.
} 
mürettebat için peksimete de ihtiyaç duymaktaydı ki bu rakam yıllık 40,000 kantar peksimete tekabül etmekteydi ${ }^{47}$. Ancak ham demirin kantar başına maliyeti peksimete göre daha fazlaydı. Örneğin 18.yüzyılın büyük kısmında devletin ham demir için kantar başına yapmış olduğu harcama 4-5 kuruş iken, peksimette bu rakam, 17.yüzyıl fiyatları ölçü alındığında 20 akçe kadardı ${ }^{48}$.

Demir konusunda Samakov, Sofya, Filipe, Dubniçe ve Radomir kazalarının ahalisi ocaklık usulüne tabiydi ${ }^{49}$. Bu kazalar içinde Samakov'un gerek Tersane-i Âmire gerekse Tophane-i Âmirenin ihtiyaç duyduğu ham demiri sağlama konusunda özel bir yeri vardı. Burası Osmanlı hâkimiyetine girmeden önce de demir madenciliği ve demir üretimi ile ön plana çıkmıştı. Samokov, Bulgarca'da “demir döven” anlamına gelmektedir. 1453/1454 yılına ait bir tapu tahrir kaydı burada çok önemli demir yataklarının mevcudiyetini, demir üretiminin geliştiğini ve birkaç Samakov köyünün belirli sayıda demir dövücüye ve eritme firınlarına sahip olduğunu göstermektedir ${ }^{50}$. Bu yüzden yöre ahalisi devlete yapmış olduğu ham demir üretimi için, önemli miktarda vergi ödemekteydi. 1544 y1lında Samakov'dan tahsil edilen vergi, 166,629 akçe olup bunun 72,364 akçesi burası ve komşu köylerdeki demirlerin tartılmasından elde edilen kantar vergisiydi. 18. yüzyıl başında Kont Marsigli, Samakov'un Tersane-i Âmire’ye yılda $78,120 \mathrm{~kg}$ ham demir gönderdiğini belirtmiştir. Buradaki demir üretimi 19. yüzyılda daha da artarak 1869 yılında 2,775,000 kg'a ulaşmıştır ${ }^{51}$.

Samakov kazası ahalisi, 1762/1763 y1l itibarıla her 1000 kantar $(56,408 \mathrm{~kg})$ demirden 150 kantarını (8461 kg.), devlete "fiyat-ı miri" üzerinden sağlamakla yükümlüydü ${ }^{52}$. Ancak dönemin koşulları nedeniyle, kaza ahalisi bunu fazla bularak bu miktar için bir indirim talep etmiş lakin bunun kabul edilmeyerek bu miktarda demirin ssrarla talep edilmesi buradaki ahalinin şikâyetine neden olmuştur. Samakov madeninin başında bir tane kamu görevlisi bulunmaktaydı ki bu kişinin unvanı Samakovcuk

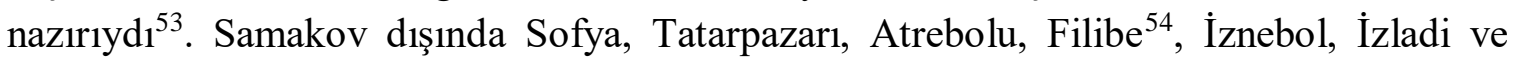
Eğridere kazaları da demir üretilen kazalar arasındayd ${ }^{55}$. Kavala, Serez, Zihne, Pravişte,

${ }^{47}$ Aziz Altı- Salih Başkutlu, "Bebek Peksimethanesi”, Osmanlı Mirası Araştırmaları Dergisi, 7/18, 2020, s. 420.

${ }^{48}$ Aziz Alt1-Salih Başkutlu, agm. , s.

${ }^{49}$ Yusuf Alperen Aydın, age., s. 282.

${ }^{50}$ Machiel Kiel, "Samakov", TDV İslam Ansiklopedisi, Cilt 36, İstanbul 2009, s. 62.

${ }^{51}$ Machiel Kiel, agm., s. 63.

${ }^{52}$ Sofya ve Atrebolu ahalisi de bu oran üzerinden devlete demir sağlamaktaydı. Oranın yüksek görülmesi üzerine Tatarpazarı mahkemesinde bu orana güç yetiremeyecekleri gerekçesiyle itiraz etmişler ve bu oranın 1000 kantarda (56,408 kg) 100 kantar (5640 kg.) veya 50 kantar $(2820 \mathrm{~kg})$ olmasını talep etmişler ise de Tatarpazarı kadısının bunu İstanbul'a bildirmesine rağmen bu talep devlet katında kabul görmemiştir. Vidin muhafizı ile Tatarpazarı ve Atrebolu naiblerine konuyla ilgili olarak 18 Cemaziyülevvel 1176 (5 Aralık 1762) tarihinde yazılan hüküm için bk. BOA.MAD.d.9989.60.

${ }^{53}$ Mehmet Zeki Pakalın, age., Cilt 1., s. 29.

${ }^{54}$ Adı geçen kazalarla ilgili sadrazamlık çuhadarlarından olup memuriyet göreviyle Filibe'ye giderek geri dönen Abdullah'ın hazırlamış olduğu 20 Recep 1191 (24 Ağustos 1777) tarihli evrakın özeti için bk. BOA.C.BH.30.1438.1.1.

${ }^{55}$ Yusuf Alperen Aydın, age. , s. 282.

\section{ULUSLARARASI EĞİTIM VE TARİH ARAŞTIRMALARI DERGİSI}

(ETA JOURNAL)

INTERNATIONAL JOURNAL OF EDUCATION AND HISTORY RESEARCH

Yll: 4, Sayı: 1, Ocak 2022, s.24-67. 
Radovişte, Demirhisar ve Usturumca kazaları ise Rumeli'de ihtiyaç halinde ham demir satın alınan kazaların başında gelmekteydi ${ }^{56}$.

Kazalardan satın alınan ham demir, birbirini tamamlayan kara ve deniz yolları vasitasıyla İstanbul'a sevk edilmekteydi. Uygulama olarak doğrudan İstanbul yerine İstanbul dışındaki farklı tersanelere de bu kazalardan bazen demir gönderildiği görülmektedir. Örneğin, Kavala, Serez, Zihne, Pravişte, Usturumca ve Eğridere kazalarından toplanan ham demir, Selanik iskelesi vasitasıyla Misır'da bulunan BenderSüveyş tersanesine sevk olunarak burada inşası süren kalyonlar için kullanılmaktaydı ${ }^{57}$. Selanik kazası, sadece diğer kazalardan toplanan demirin sevk yeri değil aynı zamanda bu demirin üretilip devlete teslim edildiği önemli bir merkezdi ${ }^{58}$.

\section{Ham Demirin Temin Usulü}

Donanma gemilerinin kullanmış olduğu ham demir, belli usuller ve kurallar çerçevesinde işleyen yerleşik bir sistem vasıtasıyla temin edilmekteydi. Ham demiri, devletin hangi esaslar dairesinde temin edeceği, kimin ne kadar demir vereceği ne kadar ücret karşıllğı bunun yapılacağ 1 ve sorumluluğu yerine getirmemenin müeyyidesinin ne olacağ1 kanunlarla ayrıntılı bir biçimde tespit edilmişti. Bu sistem, usul ve esasları yönünden önceki yüzyıllarda işleyen temin sistemiyle aynıydı. Ancak kalyon çağına geçişle birlikte ham demire olan ihtiyacın artması sistem üzerindeki yükü artırmış bu ise önceki yüzyıllarda var olan sorunların daha sık yaşanmasına neden olmuştur.

\section{1. Ham Demir Satın Alınan Kişiler}

Devletin, ham demir temininde başvurduğu sistem esas olarak ocaklık sistemiydi. Ancak ocaklık usulüyle sağlanan ham demir, ihtiyacı karşılamaya yeterli gelmezse devlet esnaf ve tüccardan ham demir satın almak suretiyle ham demir temin etme cihetine gitmekteydi. Devlete bu yolla demir sağlayan kişilerin başında ise İstanbul'daki nalbur esnafi ile yerli ve yabancı tüccarlar gelmektedir. 1715'te esnaftan satın alınan ham demirin vukıyyesine 12 akçe, 1735 'te 15 akçe, 1738'de 15,5 akçe ve 1754 'te ise 20 akçe ödenmiştir" ${ }^{59}$. Nalbur esnafından, "narh-l cari” üzerinden demir satın alınmaktayd ${ }^{60}$. Yabancı tüccarların içinde Avrupalı ve Rusyalı tüccarlar önemli bir yer tutmaktaydı. Yabancı uyruklu demir tüccarları devletlerarası ikili ticaret anlaşmaları ya da kapitülasyon gibi hukuki muafiyetlerden yararlanarak kendi ülkesinden ham demiri,

\footnotetext{
${ }^{56}$ Rodos iskelesinde inşa olunacak 2 adet kalyonun demir ihtiyacı için sarf edilmek amacıyla adı geçen kazalardan 500 kantar ham demir satın alınması kararlaştıılmış ve bunun için 25 Ramazan 1169 (23 Haziran 1756) tarihinde 1650 kuruş ödenmesi gerekmiştir. (bk. BOA.MAD.d.10359.53.)

${ }^{57}$ Konuyla ilgili 5 Cemaziyülevvel 1176 (22 Kasım 1762) tarihinde adı geçen kazaların kadıları ile Selanik mütesellimi Ali ve Selanik gümrük emini Osman'a hitaben yazılan hüküm için bk. BOA.MAD.d.9989.117.

${ }^{58}$ Rodos tersanesinde inşa olunacak 2 adet kalyon için Selanik ve havalisinden 1170 'lerde (1756/1757) 1000 (56,408 kg) kantar ham demirin satın alınması emredilmiştir. (bk. BOA.MAD.d.10359.50.)

${ }^{59}$ Yusuf Alperen Aydın, age. , s. 283.

${ }^{60}$ Trablusgarb ocağı tarafindan talep edilen 400 kantar $(22,528 \mathrm{~kg})$ demirin, Cebehane ve Tersane-i A Âmire'den verilemeyeceğinin anlaşılması üzerine bu miktar demirin İstanbul nalbur esnafindan cari olan narh fiyatı üzerinden satın alınmasına karar verilmişti. Konuyla ilgili 11Ramazan 1168 tarihli ferman için bk. BOA.MAD.d.10357.50.
} 
gemiler vasıtasıyla İstanbul'a getirerek satabilmekteydi. Örneğin 1801/1802 y1lında Kondari adında bir Rus tüccarı, Taygan iskelesinden 1000 kantar (56,408 kg.) kadar demiri gemiyle İstanbul'a getirmişti. Ancak gerek devlet gerekse nalbur esnafi, Rus tüccarın talep ettiği fiyatı çok yüksek bulduğu için adı geçen tüccar elindeki demiri satamadan Rusya'ya geri götürmek zorunda kalmıştır ${ }^{61}$. 1815/1816 yılında ise inşa olunan kalyonlar için büyük miktarda demire ihtiyaç duyulunca gümrükçü Halil Efendi marifetiyle bir tane Rus tüccarı ile pazarlığa oturulmuş ve her bir kantarı 11,5 kuruşa 15,000 kantar $(846,120$ kg.) ham demir satın alınarak Bahçekapısı'nda bulunan Cebehane-i Âmire mahzenlerinden birisine konulmuştu ${ }^{62}$. 18. yüzyılda Rusya, özellikle Ural dağları bölgesinden çıkarmış olduğu ham demir cevheriyle, Avrupa'nın en büyük demir tedarikçilerinden birisiydi. Napolyon savaşları sırasında Karadeniz'in kuzeyinde yetişen Rus buğdayına, Avrupa'da oluşan büyük talep nedeniyle, bunları Karadeniz'in kuzeyindeki Rus limanlarından alıp Avrupa limanlarına taşıyan Rum ve Rus tüccarlar, bu dönemde İstanbul'dan geçmek zorunda oldukları için adı geçen tüccarlara bu dönemde İstanbul'da sıkça rastlanır olmuştu.

Tersane-i Âmire'de bulunan demirci esnafının kullandı̆̆ Rumeli'de Bergos, Usturumca ve Midye kazalarından temin edilirken, Anadolu'da Kara Biga, Kapıdağı ve Kocaeli sancağı gibi kaza ve sancaklar funda kökü yetiştiren yerleşim yerlerinin başında gelmekteydi ${ }^{63}$.

\subsection{Ham Demirin Temini}

Gemilerin ihtiyaç duyduğu ham demir miktarı, onların uzunluk ve büyüklüklerine göre değişmekteydi. Örnek vermek gerekirse 18 . yüzyılda 51,5 ziraa (39 m. ) uzunluğunda bir büyük kalyon için 4600 kantar $(259,476 \mathrm{~kg})$ ham demir gitmekteydi ${ }^{64}$. $1771 / 1772$ y1lında bir tane pergende ${ }^{65}$ gemisi için 200 kantar $(11,281 \mathrm{~kg})$ demir sarf edilmişti ${ }^{66}$. 1787/1788 y1lında ise 2 adet kalyona toplam 300 kantar $(16,922 \mathrm{~kg})$ ham demir gönderilmişti ki bu durumda matematiksel olarak bir kalyona 150 kantar $(8461 \mathrm{~kg})$ demir sarf edilmiş olduğu anlaşılmaktadır ${ }^{67}$. Bu gemilerin inşasında kullanılan ham demirin temininde ana usul yukarıda bahsedilen ocaklık usulü idi. Ocaklık kelimesi, Osmanlı öncesi dönemlerdeki kaynaklarda, daha çok toprak tasarrufu ve toprağın hizmet karşılığındaki kullanım hakkının belli bir aileye bırakılmış olması bağlamında zikredilmektedir. $\mathrm{Bu}$ anlamın dışında devletin bir kısım giderlerinin karşılanması için

\footnotetext{
${ }^{61}$ Rus orta elçisi tarafindan Kondari isimli Rus tüccarın Karadeniz'e dönmesi hususunda ona engel olunmaması için Osmanlı Devleti makamlarına hitaben yazılmış olan arzuhal için bk. BOA.C.HR.25.1227.1.1.

62 BOA.C.BH.146.7017.1.2.

${ }^{63}$ Tersane-i Âmire kömürü tamamlanmadıkça, muhtekir ve madrabaz taifesine funda kökü satılmaması hakkında Rumeli ve Anadolu taraflarında bulunan kadılara hitaben 17 Zilkade 1163 (18 Ekim 1750) tarihinde yazılan ferman için bk. BOA.MAD.d.10350.54.

${ }^{64}$ BOA.MAD.d.10392.62.

${ }^{65}$ Pergende gemisi, küreği ana hareket unsuru olarak kullanmakla birlikte yelkeni yardımcı olarak kullanan çektiri türü bir savaş gemisiydi.18/19 oturağa sahip ve 33-40 ziraa $(25-30 \mathrm{~m}$.)uzunluğundaydı. (İdris Bostan, Osmanlı Bahriye Teşkilatı, 17.Yüzyılda Tersane-i Âmire, Türk Tarih Kurumu, Ankara 2003, s. 84)

${ }^{66}$ BOA.MAD.d.10386.67.

${ }^{67}$ BOA.MAD.d.2925.94.
}

\section{ULUSLARARASI EĞİTIIM VE TARİH ARAŞTIRMALARI DERGİSİ} (ETA JOURNAL) 
bazı gelir kaynaklarının tahsisine de ocaklık denilmektedir ${ }^{68}$. Ham demirin temini için kullanılan ocaklık kavramı bu son çeşit ocaklıkları ifade etmektedir.

Ham demir, genellikle ocaklık usulü gereğince kanunla tayin edilmiş kazalar ahalisi tarafından hazırlanıp Tersane-i Âmire'ye teslim edilen bir malzemeydi. Ocaklık usulü dışındaki diğer usullerle temin edilen demir miktarı, toplam demir miktarı içinde oldukça cüzi bir miktar teşkil etmekteydi. Ocaklık usulüyle toplanan demirin belli özellikleri taşıması gerekiyordu. Örneğin sağlam ve kullanıma uygun olması icap etmekteydi. Çünkü, sadece bu durumdaki ham demir kendisinden beklenen faydayı sağlayabilmekteydi. 30 Ağustos 1777 tarihinde Filipe nazırı Ömer'in Sofya'dan satın alarak İstanbul'a gönderdiği ham demir, padişah tarafindan tenkit edilirken; “...bu defa Deraliyye'me vürud iden âhen-i ham mağşuş ve mühimmat-ı âheni imal, bir tarikle mümkün olmadĭ̆g..." hususu ifade edilmişti. Bu ifadenin mefhumu muhalifinden yola çıkılırsa, demirin sağlam olması ifadesi, içindeki demir cevherinin belli bir oranın üstünde olması anlamına gelirken kullanıma uygun olması ifadesi ise kendisinden demir araç gereçlerin imal edilmesine uygun olması anlamına gelmektedir ${ }^{69}$. Ham demirin temini için kurulan düzen ve bu iş için seferber edilen bütün memur ve bütçenin amac1, sağlam ve kullanıma uygun ham demiri temin ederek gemi ustalarının emrine sunabilmekti.

Ham demirin temininde yasayla tayin edilmiş süreler vard1. "Sene-i atiye" olarak isimlendirilen gelecek senenin mart ayında, sefere çıkacak olan donanmanın ihtiyacı olan demir, bir önceki seneden (sene-i sabıka) ilgili yer ve kazalardan temin edilmeye başlanırd $1^{70}$. Demirin zaman olarak "mevsim-i sayf" olarak belirtilen yaz mevsiminde Tersane-i Âmire’ye teslim edilmesi gerekmekteydi. Bunun da birtakım gerekçeleri vardı. Örneğin, kış mevsimi geldiğinde demirin karayoluyla nakli, kar, soğuk ve yağmur gibi olumsuz iklim koşullarının etkisiyle güç bir hale gelmekteydi. Bu olumsuz iklim koşulları nedeniyle, yollar çamur ya da karla kaplandığı için hem ahaliyi bu iş için seferber etmek zorlaşıyor hem de işin ücret maliyeti artıyordu. Ayrıca kalyon inşasının hızlandığı dönem yaz mevsimiydi. Bu mevsimde kalyon inşası için lüzumlu olan kereste, yelken bezi, kendir, katran ve zift gibi inşa malzemeleri ile demirci, marangoz, burgucu ve oymac1 gibi iş gücünü bir araya getirmek daha kolay hale geliyordu ${ }^{71}$.

Devletin, demiri İstanbul'a taşımak için tercih ettiği yol, coğrafi nedenlerle genelde kara yolu olsa bile deniz yolunu da imkân ölçüsünde kullanmaya özen gösteriyordu. Demirin kara yoluyla Edirne'ye geldikten sonra buradan doğrudan doğruya İstanbul'a taşınması yerine Tekirdağ'ına taşınarak buradan deniz yoluyla İstanbul'a taşınması,

\footnotetext{
${ }^{68}$ Mehmet Taş, age. , s. 139.

${ }^{69}$ BOA.C.BH.30.1438.1.1.

70 “....inşallahü te'ala sene-i âtiyede rû-yi deryaya ihraç olunacak donanma-yı hümayun kalyonları sair cebehane ve tophane vesair lazıme için, sene-i sabıkada mubaya'a olunduğu üzere kaza-1 mezkurlardan 7000 Samakov kantar $(394,240 \mathrm{~kg})$ ahen-i ham şimdiden ol cevaniblerde olan samakovlardan bir gün evvel mubaya'a...(7 Recep 1129/17 Haziran 1717)" (bk. BOA.MAD.d.2864.33.)

71 İzmir Voyvodası Katipzade el-Hac Mehmet Ağa, Bodrum sahasında inşa olunan bir adet kalyonun yaz mevsiminde bitirileceğini İzmir'de kaptan paşaya taahhüt etmesi üzerine geminin demir malzemelerinin üretimi için Mahzen-i Sürb’ten 150 kantar (8461 kg) demir talep etmişti. (bk. BOA.C.BH.51.2417.1.1.).
} 
devletin deniz yolunu bu iş için daha uygun ve daha ekonomik bulduğunu göstermektedir. Demirler, deniz yoluyla taşınacağı zaman gemi ve kayıkların safra mahalline 100-200 kantarlık (5632 kg - 112,6 kg) ağırlıklarla yerleştirilir ve bu şekilde oluşan fazla ağırlık nedeniyle geminin dengesinin bozulması önlenmiş olurdu ${ }^{72}$. Deniz yoluyla taşımacılık kara yoluyla taşımacılığa kıyasla daha ucuz ve verimliydi. Deniz yoluyla taşımacılığın alternatifi hiç şüphesiz kara yolu taşımacılığıydı. Ancak bu alternatif hem daha pahalı hem de daha yavaştı. Hayvanların tükettiği yem, taşıdıkları maldan daha büyük bir yük oluşturduğu için kara yoluyla nakliyat çok kısa mesafeler dışında gerçekçi bir seçenek sayılamayacak kadar pahalıydı. Erken modern dönemin, en küçük tekneleri bile, en iyi kara taşımacılığı türünde taşınan yükün 200 katı kadar yük taşıyabiliyordu ${ }^{73}$.

Demir nakliyatı söz konusu olduğunda, deniz ve kara taşımacılığının birlikte kullanıldığı karma bir usul izlenmekteydi. Osmanlı yük taşımacılığında kara yolu nakliyatı ise araba ve yük hayvanları ile olmak üzere 2 şekilde gerçekleşmekteydi. Yük hayvanları olarak arazi ve iklim koşullarına göre deve, at, katır ve nadiren de olsa eşek kullanılmaktaydı. Camus, manda ve öküz ise daha çok arabalara koşulmakta ve yük arabalarının sürülmesinde kullanılmaktaydı. Nakliye işinde bu hayvanların temini söz konusu olduğunda ise 2 yola başvurulmaktaydı. Bunlar satın alma ve kiralamaydı. Bunları satın almak daha cazip gibi görünse de maliyet açısından elverişli değildi. Çünkü 5-6 aylık bir süre dışında bunlar kullanılmayıp âtıl kaldığında, bu hayvanların bakım, barınma, beslenme ve görevli masrafları ile kendilerinden sağlanan faydayı tersine çeviriyordu. 12 aylık sürede bu hayvanlar bir süre yük taşırken, daha büyük bir süre âtıl kaldıkları için kendileri birer yüke dönüşüyordu. Oysa kiralama usulünde, kira ücreti yüksek gibi görünse de yük hayvanları sadece ihtiyaç duyulduğunda kiralanmakta ve devlet bunların yem, otlak ve bakım giderleri ile görevli masraflarından kurtulmaktaydı. $\mathrm{Bu}$ da yük hayvanlarını kiralamayı, devlet açısından daha uygun hale getirmekteydi. Demir naklinde devlet kiralama usulüyle birlikte bir çeşit vergilendirme diyebileceğimiz mükellefiyet olarak bu işi reayaya yaptırma usulünü de kullanmıştır ${ }^{74}$. Demir nakliyatında ön plana çıkan şehirlerden olan Edirne ve onun da bir parçası olduğu Rumeli'de deve, katır vs. hayvanlar için hazinenin otlakları vardı ve buralarda ordunun ulaştırma ihtiyacı için hayvan yetiştirilmekteydi ${ }^{75}$. Bu husus demirin buradan taşınması meselesiyle ilgili değerli ip uçları vermektedir.

\footnotetext{
${ }^{72}$ Rodos adasında inşa edilen 3 adet kalyon için Çeşme limanından gönderilen 1500 kantar $(84,480 \mathrm{~kg})$ demir İstanköy, Bodrum ve Rodos tarafina giden kayıkların safra mahalline yerleştirilerek yola çıkarılmıştı. 1 Şevval 1186 (26 aralık 1772) tarihli ferman için bk. BOA.MAD.d.10386.80.

${ }^{73}$ Donald Quataert, Osmanlı İmparatorluğu 1700-1922, Çeviren: Ayşe Berktay, İletişim yayınları, 3.Baskı, İstanbul,2004, s. 181.

74 Ömer İşbilir, "Savaş ve Bölgesel Ekonomi: İran Savaşlarında Doğu Karadeniz ve Doğu Anadolu", OTAM (Ankara Üniversitesi, Osmanlı Tarihi Araştırma ve Uygulama Merkezi Dergisi), Cilt 2007,Sayı 21,2007, s.25-26.

${ }^{75}$ Kaya Göktepe, "Osmanlı Döneminde Tekirdağ'da yapılan Hayvancılığın İstanbul'un İaşesi İle Sanayi ve Ticari Faaliyetlerindeki Rolü”, Trakya Üniversitesi, Sosyal Bilimler Dergisi, Haziran 2018,Cilt 20,Sayı $1, \mathrm{s.364 \text {. }}$
} 
Tersane-i Âmire için, ham demire ihtiyaç duyulduğunda, bu ihtiyaç miktarıyla birlikte Tersane emini tarafindan bir arz halinde yazıya dökülerek padişaha sunulmaktaydı. Padişahın bunu onaylayan fermanından sonra talep edilen ham demirin fiyatı, baş muhasebe tarafindan hesaplanarak defter haline getirilmekte ve padişah fermanının da içinde bulunduğu bu defterin bir nüshası, ocaklık usulüyle demir satın alınacak kazaların kadılarına gönderilmekteydi ${ }^{76}$. Defterin bir nüshası ise ilmühaberi ile birlikte tersane emini tarafindan mübaşir tayin olunan kimseye teslim edilmekteydi ${ }^{77}$. Demir üreticileri arasında devletçe talep edilen demiri tevzi ve taksim etmek, Samakov kazası mahkemesine aitti. Mahkeme kadısı, herkesin huzurunda ferman ve konuyla ilgili defterleri açtıktan sonra, kişilerin üretim gücüne göre icap eden taksimatı yapar ve bunu şahitlerin huzurunda ilama bağlardı. Demir toplamak için İstanbul'dan gönderilen mübaşirin, kazalara gittiği zaman yanında bu ilamın bir sureti bulunurdu. Üreticiden "fiyat-ı miriye" üzere satın alınan ham demir, genelde camus adı verilen büyük baş hayvanların çektiği arabalara yüklenerek karayolu ile Varna'ya, Tekirdağ'a ${ }^{78}$ ya da Kavala'ya taşınmakta, buradan da gemilerle İstanbul'a gönderilmekteydi ${ }^{79}$. Kavala iskelesi aynı zamanda Pravişte, Draç ve Bereketli kazalarından toplanan ve ateşli silahlarda mühimmat olarak kullanılan maden ve taş yuvarlakların da İstanbul'a sevk yeriydi ${ }^{80}$. Ağırlık taşımada kullanılan yük arabaları ise Edirne, Dimetoka ve Cisr-i Ergene kazalarından ücret karşılığı tutulmaktayd1 ${ }^{81}$. İhtiyacın düzeyine göre ve yeri geldiği zaman, ücreti peşin ödenmek koşuluyla Filipe, Pazarcık, İhtiman, Sofya, Samakov ve Dubniçe kazalarından da camus arabaları temin edilmekteydi ${ }^{82}$. Tatarpazarı ve Filibe'den

\footnotetext{
${ }^{76}$ Cebehane-i Âmire'den Tersane-i Âmire'ye gönderilen ham demir de aynı şekilde baş muhasebeye kayd olunur ve kaydın bir sureti ilgililere verilirdi.7 Rebiyülahir 1186 (8 Temmuz 1772) tarihinde Tersane-i Âmire'de inşa olunan 2 adet kalyon ile 2 adet büyük pergende gemisi için Cebehane-i Âmire'den 500 kantar $(28,204 \mathrm{~kg})$ ham demir gönderilmesi kararlaştırılmıştı. Karar, baş muhasebeye kayıt olunmuştu. (bk. BOA.C.BH.250.11564.1.)

${ }^{77}$ Mübaşir, Osmanlı idare teşkilatında sıkça kullanılan bir terimdir. Bu terim, 18. yüzyılda devletçe gördürülmesi lazım gelen bir işin yapılmasına memur edilen kimseler hakkında kullanılan bir terimdir. Anlam olarak Arapça "bir işe başlayan, başlayıcı" anlamına gelmektedir. Demir için atanan mübaşirin yol masrafi merkezi idare tarafindan tahsis edilen ödenekten karşılanmakta iken sair işler için atanan mübaşirlere devletçe yol masrafi verilmez, her türlü yol masrafları gittikleri yerlerin tevzi defterlerine geçirilmek suretiyle halk tarafindan karşılanırdı. (bk. Mehmet Taş, age., s. 141.)

${ }^{78}$ Tekirdağ'a gelen ham demirin tüccarlara ya da başka kimselere satılmaması için Tekirdağ kadısı ya da naibine hükümler yazılmaktaydı. Tüccarların ham demiri satın almak istemeleri devletçe belirlenen miri fiyat yani narh fiyatı ile piyasa fiyatı arasındaki farkın büyümüş olmasından kaynaklanmaktaydı. Tüccar, devletin belirlediği fiyattan daha yüksek bir fiyata ham demiri satın almakta aha sonra da bunu piyasa fiyatından nalburcu ve serbest çalışan demirci esnafina satarak kar elde etmekteydi. Konuyla ilgili Rodosçuk naibine Evail Recep 1106 (Şubat/Mart 1695) tarihinde yazılan hüküm için bk. BOA.A.DVNS. MHM.d.103.27.

${ }^{79}$ Camus tabir olunan hayvanlar sığırlardan farklı bir tür olup onlardan daha iri yapılı, daha güçlü ve mevcut koşullara daha hızlı uyum sağlama yeteneğine sahip bir hayvandır. Ayrıca sığırlara kıyasla daha az yem ve saman tüketmektedir. Sığırların tüketmediği kaba yemleri tüketebilmektedir. Halk arasında daha çok manda olarak bilinmektedir. (bk.Güven Şahin, "Türkiye Zirai Hayatında Manda (Bubalus Bubalis) Yetiştiriciliği ve Manda Ürünlerinin Değerlendirilmesi”, İstanbul Üniversitesi Edebiyat Fakültesi Coğrafya Dergisi, Sayı 31, İstanbul 2015, s. 18.)

${ }^{80}$ Konuyla ilgili Pravişte, Kavala, Bereketli ve Dıraç kadıları ile Pravişte karhane emini Mehmet çorbacıya hitaben 26 Zilkade 1122 (16 Ocak 1711) tarihinde yazılan hüküm için bk. BOA.MAD.d.3435.17.)

${ }^{81}$ BOA.MAD.d.9848.21.

${ }^{82}$ Yusuf Alperen Aydın, age. , s. 284.
} 
satın alınan ham demirler, mekkari arabaları ve hamallarla Filipe üzerinden Edirne'ye oradan da parça parça Tekirdağı iskelesine taşındıktan sonra buradan gemilerle İstanbul'a nakledilmekteydi ${ }^{83}$. Ancak bu usul her zaman mükemmel işlemiyordu. Örneğin Edirne'den Tekirdağ'ına kadar demir taşımada kullanılan mekkari arabalarının, her zaman yeterli miktarda bulunması mümkün olmuyordu. Mesela demirin nakli, ahalinin hasat ve harman zamanına tesadüf etmişse araba bulmada sorun çıkıyordu. Çünkü arabalar ya hasat sahipleri tarafından önceden kiralanmış olmakta ya da bizzat arabanın sahibi onu kendi tarımsal işleri için seferber etmiş durumda bulunmaktadır ${ }^{84}$. Bu ise devletin mekkari arabaları için yaptığı harcamanın tutarını artırmaktaydı. Demirin gemilere yüklendiği iskelelerde görev yapan gümrük eminlerinin kendilerine teslim olunan demiri "vezn ve kantar" ederek teslim alması gerekiyordu ${ }^{85}$. Burada tutulan kayıtlar hem taşıma işini üslenen kişilerin hem de iskele eminlerinin zimmet hesaplarının çıkarılmasında kullanılıyordu. Örneğin Mahzen-i Sürb'e teslim edilen demirin miktarı ile Tekirdağ iskelesinde gümrük emini tarafindan teslim edilen demirin miktarı, birbirini tutmazsa, aradaki fark demiri taşıyan gemi kaptanından tahsil edilmekteydi. Bu tahsilat genelde kayıp olan demirin ücreti kadar bir tutarın gemi kaptanına ödenecek navluna mahsup edilmesi şeklinde gerçekleşmekteydi.

İskelelere nakil için gerekli olan araba, hamal, yükleme ve navlun ücreti peşin olarak sahiplerine ödenmekteydi. Bunlar içinde navlun ücreti, ham demiri denizde gemilerle taşıma hizmeti karşılığı olarak gemi kaptanlarına ödenmekteydi. 18. yüzyılın ikinci yarısına kadar navlun ücreti kantar başına 7 akçe idi. Bunun dışında iskele başında gemilere kantar başına 1 akçe kantariye ve bir miktar da hamaliye ücreti de ödenmekteydii ${ }^{86}$. Bütün bu işlemler Tersane-i Âmire tarafindan gönderilen bir mübaşir nezaretinde gerçekleşmekteydi ${ }^{87}$. Mübaşirler istikamet ve liyakat sahibi kimselerden seçilmekteydi. Genelde donanma ve tersane kariyeri olanlar bu iş için seçilseler de bunların mutlaka denizci kökenli olması gerekmiyordu. İş bilir, sadık ve liyakat sahibi olmaları bu iş için atanmalarına yeterliydi. Aynı iş için birden fazla mübaşir de tayin edilebilirdii ${ }^{88}$. Mübaşirin başlıca görevi demiri toplamak, İstanbul'a taşıtmak ve Tersane-i Âmire içinde bulunan Mahzen-i Sürb'e teslim etmekti. Bu iş için gerekli olan ücretler kendisine önceden peşin ve nakit olarak ödenmekteydi. Mübaşirin görev yerinde bulunan kadı, naip, ayan ya da iş erleri ona bu konuda ona yardımcı olmakla yükümlüydü ${ }^{89}$. Mübaşirler ellerindeki deftere göre vardıkları kazalarda yaşayan ocaklık yükümlüsü ahaliden ücreti önceden peşin olarak ödenmiş olan demiri tahsil ederlerdi. Onlar, ocaklık yükümlüsü olan ahaliye “...bahasını ashabına eda ve teslim ve bir kimsenin bir akçesini ketm ve kat' olunmayub... " ifadesi ile belirtildiği üzere ücreti eksiksiz olarak

\footnotetext{
${ }^{83}$ BOA.MAD.d.10359.40.

${ }^{84}$ BOA.MAD.d.104.12.119.

${ }^{85}$ BOA.MAD.d.10384.42.

${ }^{86}$ Yusuf Alperen Aydin, age. , s. 284.

${ }^{87}$ BOA.MAD.d.10359.53.

88 Samakov tarafından 400 kantar $(22,563 \mathrm{~kg}$.) Abdullah çavuş tarafından tahsil edilerek Tekirdağ’a taşınmış burada Tersane-i Amire tarafından görevlendirilen Mehmet Çavuş’a teslim edilmiştir. Mehmet Çavuşa bu miktar demiri İstanbul'a getirmesi emredilmiştir. (bk. A.DVNS. MHM.103.12.)

${ }^{89}$ BOA.MAD.d.4375.92.
}

ULUSLARARASI EĞITIMM VE TARIH ARAŞTIRMALARI DERGISİ

(ETA JOURNAL)

INTERNATIONAL JOURNAL OF EDUCATION AND HISTORY RESEARCH

Yıl: 4, Sayı: 1, Ocak 2022, s.24-67. 
ödemeliydiler ${ }^{90}$. Ellerindeki ferman, onların görev ve yetkilerini tayin eden ve herkesi bağlayan bir tür anayasa niteliğindeydi. Kendilerinden istenen demiri, bu anayasaya göre Tersane-i Âmire'ye teslim ettikten sonra yeni bir ferman kendilerine verilmeden aynı sene içinde yeniden devlet adına demir tahsil edemezlerdi ${ }^{91}$. Demir temini işinin mutlak surette tersane emini tarafindan atanmış bir mübaşir vasıtasıyla gerçekleşmesi de gerekmiyordu. Bazen onun atayacağı bir mübaşir yerine daha üst düzey bir devlet görevlisi de ham demir temini işini çözebilirdi ${ }^{92}$.

Devlet, ücret konusunda ahalinin çıkarını gözeten bir yaklaşımla taksit ya da para dışında bir ödeme biçimini kabul etmemişti. Parayla yapılacak ödeme, peşin ve nakit olarak gerçekleşmekteydi. Bu ödeme özünde, devletçe tayin edilmiş bir narh fiyatı olan "miri baha" üzerinden yapılmaktayd1. Miri mubayaa rejiminin özünü oluşturan "miri baha" kavramı, hammadde ve emek ücretlerinin diğer iktisadi faktörlerden bağımsız olarak devlet tarafından dondurulmuş olduğu bir fiyat politikasını ifade etmekteydi. Üretici her sene devlet tarafindan ne kadar kendisine ücret ödeneceğini bilmekte ve ona göre üretim araçlarını üretime koşmaktadır. Ancak ekonomi istikrarlı iken bu uygulama ahali açısından fazla bir hoşnutsuzluğa yol açmıyorken ekonomik istikrarın bozulduğu dönemlerde halk açısından ağır bir yük halini almıştır. Çünkü yüksek enflasyon koşullarında onlara verilen ücretin nominal olarak aynı kalırken reel olarak küçülmesi üreticinin alım gücünü geriletmiştir.

Yelken bezi ve peksimet temininde görüldüğü gibi mübaşire Tersane-i Âmire'de tarafindan bir numune sunulması ve bu numuneye göre bu malzemeleri toplaması emredilmişken ham demir temininde böyle bir uygulama yoktur. Ancak demirden mamul malzemelerin temininde bu usule riayet edilmekteydi. Örneğin 1792/1793 y1lında demir çivi yerine ahşaptan kavalye çivisi yapımı emredildiğinde, mübaşire 3 adet numune verilmişti. Ondan bu numunelere göre 30,000 kadar kavalyelik pırnal ağacı satın alması istenmişti ${ }^{93}$.

Devletçe atanmış mübaşir ile ham demir sağlayan ocak yükümlüsü ahali arasındaki ilişki bir tarafin diğer tarafa dilediği her fiyatı dayatabileceği tek taraflı bir ilişki değildi. Ahali kendisinden talep edilen demirin miktarına itiraz edebiliyor ve haklı gerekçeler ileri sürerek devletten indirim talep edebiliyordu. Bu talepleri haklı bulunursa gecikmeden yerine getiriliyordu. Bunun için kazaların ahalisi toplu halde ya da bireysel olarak kazada bulunan mahkemeye başvurarak talebini kayıt altına aldırıyordu. Kaza kadıları ve onların naipleri tarafindan bu talepler, ilam haline getirilerek İstanbul'a gönderilmekteydi. Devlet

\footnotetext{
${ }^{90}$ Dergâh-1 âli gediklilerinden olup Samakov tarafina ham demir satın almaya gönderilmiş Yusuf'a 17 Rebiyülevvel 1176 (6 Ekim 1762) tarihinde yazılan konuyla ilgili hüküm için bk. BOA.MAD.d.9989.40.

91 “....miri tarafindan ferman olan beş yüz kantar $(28,204 \mathrm{~kg})$ demir tamamen teslim olunduktan sonra bilaemr-i şerif tekrar miri namıyla tüccara rencide olunmaya deyu...”(bk. BOA.MAD.d.9848.7.)

${ }^{92}$ Tersane-i Âmire'de inşa olunan 3 kantarlı kalyon için Filipe, Tatarpazarı ve Samakov'dan ham demir satın almaya 1170 (1756/1757) yılında Matbah-1 Âmire Emini Abdurrahman Bey tayin edilmişti. (bk. BOA.MAD.d.10360.47.) 1169 (1755/1756) yılında Samakov, Filipe, Sofya, Tatarpazarı ve Zihne'den 5000 kantar $(282,040 \mathrm{~kg})$ ham demir, İstanbul cizyedarı Abdurrahman tarafindan satın alınarak İstanbul'a gönderilmiştir.(bk. BOA.MAD.d.10359.40.)

${ }_{93}$ BOA.C.BH.247.11461.2.1.
} 
bu talebi haklı bulursa demir hissesini indiriyor, haklı bulmazsa mevcut hisselerde eskisi gibi demirin toplanmasını emrediyordu. 1762/1763 y1lında Sofya ve Atrebolu ahalisi yeni durumda, eski hisselerine kıyasla bir buçuk kat fazla demir talep edildiği gerekçesiyle itiraz etmişler ve eski hisseleri üzerinden demir teslim etmeye devam edeceklerine dair taleplerini, Lofça ve İzladi kadıları ile Tatarpazarı ve Atrebolu naipleri vasıtasıyla İstanbul'a ulaştırmışlardı. Onlar her 1000 kantarda (56,408 kg.) 150 kantar (8461 kg) değil eskiden olduğu gibi 100 kantar (5640 kg.) ya da 50 kantar $(2820 \mathrm{~kg})$ demir ödemek istediklerini belirtmişlerdi. $\mathrm{Bu}$ tekliflerinin ötesinde demir vermeye ne demir madenlerinin kapasitesi ne de kendilerinin mali gücü yeterli gelmiyordu. Ancak talepleri, ihtiyaç duyulan demirin zamanında karşılanmasına engel olacağı gerekçesiyle merkezi yönetim tarafindan reddedilmişti ${ }^{94}$. Bu örnek devlet ve ahali arasında demir temini konusunda tarafların birbirini etkileyebildiği çift taraflı bir ilişkinin var olduğunu göstermektedir.

Demir temininde, tersane eminlerinin geniş yetkileri vardı. Onlar, ham demiri usulüne uygun olarak miri fiyatı üzerinden ocaklık usulüyle ya da serbest piyasadan satın alabileceği gibi doğrudan İstanbul'daki demirci esnafina başvurarak da demir eşyaları yaptırabilirdi. Tersane eminin yaptı̆̆ 1 harcamanın bedeli, baş muhasebeye kayıt olunmakta ve bu meblağ onun hesabına mahsup olmak üzere ona bir defter sureti verilmekteydi. $\mathrm{Bu}$ iş için onun sarf etmiş olduğu para, devlete olan borcuna mahsup edilmekteydi. Bu durum Tersane-i Âmire ruznamçesine de işlenirdi. 28 Nisan 1772 tarihinde Tersane Emini el-Hac Yusuf Efendi, 40 adet firkate için ihtiyaç duyulan 250 adet çengel demirini 12,740 kuruş ücret karşıllı̆ında Galata'da bulunan demircilere imal ettirmiş ve bu ücret onun hesabına mahsup edilmişti ${ }^{95}$.

Tersane-i Âmire'nin ihtiyaç duyduğu demirin temininde bazen başvurulan istisnai bir diğer yöntem de yaşlandığı için ya da tamir kabul etmez biçimde hasar gördüğü için feshedilmek zorunda kalınan gemilerin, feshedildikten sonra artan demirlerinin Mahzen-i Sürb'e kaldırılmasıydı. Feshedilen gemilerin İstanbul'da ya da taşra tersanelerinde olması fark etmiyordu. Bu durumda tersaneye gelen demir, tersane eminine irad kayit olunarak inşa ya da tamir olunacak gemiler için kullanılmaktaydı. 1784/1785 yılında Tersane-i Âmire'de tamir olunacak kalyonlar için farklı türlerde çiviye ihtiyaç duyulduğunda, gerek Tersane-i Âmire'de ve gerekse Cebehane-i Âmire'de bu iş için yeterli miktarda demir kalmadığ 1 anlaşılınca, 3 Eylül 1785 tarihinde, Tersane-i Âmire içinde fesh olunan bir kalyonun artan demirlerinin kullanılmasına karar verilmişti ${ }^{96}$.

Bu uygulamada, liman reisi, sökülen ve parçalarına ayrılan gemilerden elde edilen malzemeleri kullanıma uygun olan ya da olmayan şeklinde bir defter haline getirerek, her iki türden demirleri de Mahzen-i Sürb'e depo ettirmekteydi. Depo işlemi sırasında demirler tartıldıktan sonra mahzen defterine kayıt olunmakta ve Hazine-i Âmire defterlerine de kayıt edilmesi için gerekli bildirimler görevliler tarafından

\footnotetext{
${ }^{94}$ BOA.MAD.d.9989.60.

95 BOA.MAD.d.3014.65.

${ }^{96}$ Tersane Emini el-Hac Selim Ağa'nın konu bağlamında yazmış olduğu dilekçenin içeriği hakkında bk. BOA.MAD.d.2925.84.
}

ULUSLARARASI EĞİTIM VE TARİH ARAŞTIRMALARI DERGISİ

(ETA JOURNAL)

INTERNATIONAL JOURNAL OF EDUCATION AND HISTORY RESEARCH

Yıl: 4, Sayı: 1, Ocak 2022, s.24-67. 
yapılmaktayd $1^{97}$. Demirin, keresteye göre daha uzun kullanım ömrüne sahip olması ve ona duyulan ihtiyacın büyüklügü devlete bu imkânı sunarken aynı zamanda devlete maliyet unsurlarını düşürerek tasarrufta bulunma imkânı da sağlıyordu. 19 Mayıs 1713 tarihinde inşası ferman olunan 3 adet kalyon için ham demir ve çiviye ihtiyaç duyulduğunda, Tersane-i Âmire içinde bozulan eski kalyonlardan çıkarılıp Mahzen-i Sürb'e depolanan çivi ve demirlerin kullanılması emredilmişti ${ }^{98}$. İstanbul dişındaki tersanelerde gemi inşa edilirken, kale tamirinde kullanılan demirlerin de zaman zaman kullanıldığı anlaşılmaktadır. 1786/1787 yılında, Sinop kalesi tamiri için Sürmeli Hafız Ağa'nın depolamış olduğu demirler, Sinop tersanesinde inşa olunan 2 adet kalyonun demir ihtiyacı için Kastamonu mütesellimi el-Hac Ali Ağa tarafından kullanılmıştı. Onun kullanmış olduğu 84 kantar (4738 kg.) demir, hesabına gelir olarak kayıt edilmişti ${ }^{99}$.

Tersane-i Âmire sahasında bulunan Mahzen-i Sürb’te depolanan demirin, diğer tersanelere ve gemi kaptanlarına teslimi, idari bir işlem olması hasebiyle belgeler üzerinden gerçekleşirdi. Tersane emini teslim ettiği demir için ilgili kişilere mühürlü temessük verirken, onlardan aynı şekilde mühürlü makbuz alırdı. Bu makbuz gerekli yere kayıt olunur ve tersane eminine bir suret verilirdi ${ }^{100}$. Yapılan her işlemin bu şekilde belgeye bağlanması hem taraflara ispat kolaylığı sağlıyor hem de işlerin belli bir düzen ve ciddiyet içinde gerçekleşmesini mümkün kılıyordu. Bu uygulama, merkezi yönetim açısından yapılan mali ve idari işlemleri takip ederek mesele üzerinde denetim kurma imkânı da sağlıyordu. Aynı uygulama İstanbul dışındaki tersanelerde kalyon inşasına memur edilen kişiler için de geçerliydi. Onların demire ihtiyaç duyduklarına dair dilekçeleri İstanbul'a geldiği zaman, kendilerine deniz yoluyla ham demir gönderilmekteydi. Onlara taleplerinin sonucu hakkında bilgi verilmekte, şayet talepleri kabul edilmişse gönderilen gemideki demiri aldıktan sonra bunun makbuzunu Hazine-i Âmire defterlerine kayıt için geminin kaptanına vererek İstanbul'a göndermeleri emredilmekteydi. 5 Eylül 1762 tarihinde Sinop iskelesinde miri kalyon inşasına memur olan el-Hac Ahmet'ten böyle yapması istenmişti ${ }^{101}$.

Ham demirin işlenmesinde ihtiyaç duyulan iş gücü olan ve "âhenger" olarak isimlendirilen demirciler ise genelde gemi inşa olunan tersanelerin çevresindeki kazalardan seçilirdi. Örneğin Gemlik tersanesi için demirciler Marmara Ereğli ${ }^{102}$ ve Bursa'dan sağlanırken, Sinop tersanesi için Kastamonu ve havalisinden

\footnotetext{
${ }^{97}$ BOA.MAD.d.2883.42.

98 BOA.MAD.d.2883.42.

99 Sinop tersanesinde inşa olunan iki kalyonun demir ihtiyacı, toplam 300 kantar $(16,922 \mathrm{~kg}$.) kadardı. Yetmeyen demirler, Cebehane-i Âmire'den karşılanarak Sinop'a gönderilmiştir. (Bk. BOA.MAD.d.2925.94.)

${ }^{100}$ BOA.MAD.d.10350.61.

${ }^{101}$ El-Hac Ahmet, Sinop'ta inşa olunan bir adet miri kalyonun ihtiyacı için 500 kantar $(28,204$ kg.) ham demir talep ettiğinde bunun Cebehane-i Âmire'den karşılanmasına karar verilmiş ve bu miktar demir gemi ile Sinop'a geldiği zaman kendisinden bu miktar demiri teslim alması ardından da gemi kaptanına bunun makbuzunu içeren mühürlü bir temessük vererek İstanbul'a göndermesi emredilmiştir. bk. BOA.MAD.d.9989.26.

102 İnşa edilecek bir firkate için 20 adet demircinin Ereğli kazasından temin edilmesi hakkında Gurre Zilhicce 1210 (7 Haziran 1796) tarihli emr-i şerif için bk. BOA.MAD.d.10425.81.)
} 
sağlanmaktayd $1^{103}$. Bodrum tersanesi içinse İstanköy, Sakız, İzmir ve Kuşadası ile bu bölgedeki demirciler seferber edilmekteydi ${ }^{104}$. Bu uygulama sadece demircilere mahsus bir uygulama olmayıp marangoz, burgucu ve kalafatçı ustaları için de geçerli olan bir uygulamaydı. Onların bu şekilde yakın kazalardan seçilmesi, devlet açısından hem maliyet avantajı sağlıyor hem de onların bulundukları tersanelere daha kolay uyum sağlayarak memleketlerine firar etmelerini engelliyordu. İşçilerin toplanacağı kazaların kadı, naip, ayan ve iş erlerine hitaben İstanbul'dan hükümler yazılarak hareket gününden bir gün önce bu işçilerin toplanarak ilgili tersaneye gönderilmek üzere yola çıkarılması ve hızlı biçimde onların gemi inşa sahasına ulaştırılması ve bu nakliyat sırasında çok fazla özen ve dikkat gösterilmesi istenmekteydi ${ }^{105}$. Bu demir işçilerinin başına bir tane demirci başı tayin olunmakta ve onların ücretleri bu kişi vasıtasıyla onlara ödenmekteydi. Demirci başının, demir işçilerinin arasından ya da onların toplandığ1 yerden atanması yerine Tersane-i Âmire'den atandığını gösteren bazı örnekler de vardır. Ancak bu durumun zorunluluk hallerinde başvurulan bir yöntem olduğu anlaşılmaktadır. Çünkü 1 Nisan 1796'da Bursa'dan Mehmet isminde bir nazır tarafından yazılan bir dilekçede, Gemlik'te inşa olunan bir adet kalyon için Bursa'dan 15 adet demir işçisinin gönderildiği ancak Bursa'dan bunlara bir adet demirci başı tayin olunamadığ 1 bildirilerek bu işçilere Tersane-i Âmire'den bir adet demirci başı gönderilmesi talep edilmiştir ${ }^{106}$. İşçilere emeklerinin karşılı̆̆ 1 olan bu ücretin yanında hem demir hem de demiri işleyebilmeleri için ihtiyaç duydukları funda kömürünün ücreti de devlet tarafindan ödenmekteydi ${ }^{107}$. Bunun için kendilerine "kömür baha" adıyla bir ödeme yapılıp rayiç fiyatı üzerinden piyasa koşullarında ihtiyaç duydukları demiri satın almaları sağlanmaktayd ${ }^{108}$.

Kalyon inşasında "âhengaran” olarak isimleri geçen demir işçilerine ödenen ücretler masraf defterlerinde epey yer tutmaktaydı. Gerek Tersane-i Âmire'de gerekse taşra tersanelerinde inşa edilen kalyonlara ait ücret ve masraflar ayrıntılı biçimde defter haline

\footnotetext{
${ }^{103}$ Canik muhassılı el-Hac Ali Paşa tarafindan Sinop iskelesinde 51 buçuk ziraa (39 m.) uzunluğunda 2 adet kalyonun inşası için gerekli olan demir malzemelerin imali için Kastamonu tarafindan 10 adet demirci amelesinin gönderilmesi hakkında Kastamonu valisi, vilayet ayanı ve iş erlerine hitaben 4 Muharrem 1191(12 Şubat 1777) tarihli ferman için bk. BOA.MAD.d.10392.62.

${ }^{104}$ İzmir mollasına, Kuşadası ve bitişiğindeki sahilde bulunan kazaların kadı, naip ve ayanlarına hitaben 24 Zilhicce 1208 (23 Temmuz 1794) tarihinde yazılan ferman için bk. BOA.C.BH.36.1712.2.1.

${ }^{105}$ İzmir, Sakız, Kuşadası ve sair bölgelerde kazaların kadı, naip, voyvoda, muhassıl, zabitan, iş erleri ve bu iş için yazılan mübaşire hitaben 22 Muharrem 1206 (21 Eylül 1791) tarihli hüküm için bk. BOA.C.BH.25.1184.1.1.

106“....ber-vech-i muharrer üzere Bursa kadısı efendi da'ilerinin bir kıt'a i'lamı takdim olunduğunu ma'lum1 ilm ü alem ârâ-yi hazret-i velini'amileri buyuruldukta, emr-i şerif mezkurda beyan olunduğu üzere Tersane-i Âmire'den irsali lazım gelen timurcubaşının bir an akdem irsal buyurulmasına himmet-i seniyyei asıfâneleri buyurulmak bâbında..." (bk. BOA.C.BH.20.967.1.1.)

${ }^{107}$ Mustafa Tahir isimli bir kamu görevlisinin padişaha hitaben yazdığı tarihsiz bir takrirden anlaşıldığı kadarıyla, Gemlik sahasında inşa edilecek olan 51 ziraa $(38,6 \mathrm{~m}$.) uzunluğunda bir adet firkateynin demir ihtiyacı için burada 10 adet demir ocağı kurulurken buraya Bursa'dan 30 adet demir işçisi gönderilmişti. Bu işçiler ile onların kullanacağı funda kömürü Mehmet Tahir'e gönderilmiş ancak bir süre sonra iş̧̧iler ücret talep etmeye başlamışlardı. bk. BOA.C.BH.91.4397.1.1.

${ }^{108}$ Gemlik sahasında bir adet kalyon için 30 nefer demirciye demirin her bir kantarı için 110 para ücret verilip bunun 40 parası kömür bahasıydı. Onlar Tersane-i Âmire'deki demirciler hangi şekilde ve koşulda demir imal ediyorsa onlar da aynı şekil ve koşullarda demir imal etmek zorundaydı. (bk. BOA.C.BH.32.1544.1.1.)
}

\section{ULUSLARARASI EĞİTIIM VE TARİH ARAŞTIRMALARI DERGİSİ (ETA JOURNAL)}


getirilerek kayıt altına alınmıştır. Bu defterlerden bir tanesi Kaptanıderya Süleyman Paşa tarafindan Rodos adasında inşa edilen toplam 3 adet kalyonla ilgili olarak tutulmuştur. 1763/1764 tarihli bu deftere göre kalyonlarda çalışan işçiler ve bunlara ödenen ücretler kabaca şu şekildedir;

\begin{tabular}{|l|l|}
\hline Masraf Yapılan Kalem & Masrafin Tutarı (Kuruş) \\
\hline Aylakçıyan & 1765 \\
\hline Serburgucu & 512 \\
\hline Burgucu Kalfası & 308 \\
\hline Marangoz/Bıçakçı/Kalafatçı ücreti & 20,153 \\
\hline Ahengeran ücreti & 6045 \\
\hline Dağ reislerine Verilen Ücret & 1765 \\
\hline
\end{tabular}

Tablo 2. İşgücüne Ödenen Toplam Ücret İçinde Demirci Ustalarına Ödenen Ücret.

$\mathrm{Bu}$ tablodan anlaşılacağ 1 üzere demirci ustalarına ödenen ücret iş gücüne ödenen ücretim ortalama \%20,8'ni oluşturmaktadır. Bu oran marangoz, bıçakçı ve kalafatçılara ödenen toplam ücretten sonra en yüksek oranı ifade etmektedir. 18.yüzyılda Avrupalı büyük devletlerarasında gerek okyanuslarda gerekse denizlerde yaşanan çatışmalar sebebiyle donanma malzemeleri ve iş gücünün fiyatı yükselmiştir. Bu durum Osmanlı tersanelerinde istihdam edilen iş gücünün diğer emek yoğun sektörlerde istihdam edilen iş gücüne kıyasla daha çok ücret kazanıp daha müreffeh bir hayat süreceği anlamına gelmiyordu. Çünkü bahse konu iş gücünü oluşturan usta ve işçilere ödenen ücret "miri fiyat" üzerinden belirlenmiş bir ücretti ve bu ücret piyasa fiyatının altında bir ücrete tekabül ediyordu. Ocaklık usulüyle istihdam edilen iş gücü, düşük gelir düzeyinde çalışmak zorunda kaldığı için birçok zaman devletçe kendisine yüklenen bu sorumluluktan kaçma eğilimi içine girdiği görülmüştür. Bunun için birçoğu, çalıştlğ 1 devlete ait tersaneyi izinsiz terk ederek özel sektörün işlettiği iskele ve tersanelere yerleşmenin yolunu arama cihetine gitmekteydi ${ }^{109}$.

\section{Fiyat ve Ücretler}

\footnotetext{
${ }^{109}$ Midilli adasında, Seyyid Ali tarafindan inşa olunan kalyonda çalışmak için getirilen âhengeran taifesinin bir kısmı 1176 (1762/1763) tarihinde İzmir ve havalisine firar ederek kalyon inşasının tatile girmesine neden olmuştu. Konuyla ilgili ferman için bk. BOA.MAD.d.3168.79.
} 
Ham demir temininde, ücret kalemini oluşturan en önemli unsurlar, hammadde olan demir ile demiri taşımak için araba ücreti ve iskelelerden İstanbul'a nakil için gemicilere ödenen navlun ücretleriydi. Ocaklık reayasına, demir üretimi sırasında işçilik için ödenen ücret ham madde olarak demire ödenen ücretin içindeydi. Bunun için onlara ayrı bir ücret ödenmiyordu. Ham madde ücreti, temin edilecek ham demirin ocaklık usulüne tabii olup olmamasına göre değişmekteydi. Ham demir ocaklık usulüne tabi kazalardan satın alınmışsa ücretler bir tür narh fiyatı olan miri mubayaa (fiyat-ı miriye) fiyatı üzerinden sahiplerine ödenirdi. Ham demir, ocaklık rejiminin geçerli olmadığ 1 serbest piyasa koşullarında faaliyet gösteren esnaf tüccardan satın alınmışsa ücretler "rayiç fiyat" olarak bilinen piyasa fiyatı düzeyinden ödenirdi. Devlet burada tüccar ve esnafla pazarlık yapmak suretiyle demiri ya hazır halde satın alır ya da ihtiyaç duyduğu demir malzemeleri imal ettirme cihetine giderdi ${ }^{110}$.

Miri mubayaa rejiminde ödenen ücrete kıyasla, rayiç fiyata göre ödenen ücretin 18.yüzyılda istikrarlı bir seyir izlediğini söylemek mümkün değildir. Piyasaya hakim olan enflasyon, devalüasyon, durgunluk, eksik istihdam, karaborsacılık, kaçakçılık ve eksik rekabet koşulları gibi faktörler dolayısıyla ücretlerin istikrarlı bir yönde seyretmesi, piyasa dinamikleri tarafindan engellenmiştir. $\mathrm{Bu}$ durumda devletin öngörülemeyen iktisadi olayların baskısı altında bu konuda seferber etmek zorunda kaldığı mali kaynaklar daha çok artmıştır.

\section{1. Ham Demir Ücreti}

Ham demir ücreti, demir üreticilerine emek, hammadde ve üretim araçları için ödenen ücreti ifade etmekteydi. Bu ücret, ocaklık usulüne tabi yerlerde miri mubayaa rejimine göre belirlenmekteydi. Bu rejimde, birim başına ücret piyasa koşullarının etkisiyle değil devletin tek taraflı iradesiyle belirlenmekteydi. Miri mubayaa rejimine göre demir satın alınan ocaklık bölgelerindeki ham demire, kantar başına ödenen ücret şu şekildeydi ${ }^{111}$ :

\begin{tabular}{|l|c|}
\hline Y11 & $\begin{array}{c}\text { Kuruş Cinsinden Kantar Başına } \\
\text { Ödenen Ücret }\end{array}$ \\
\hline 1702 & 5 \\
\hline 1704 & 4 \\
\hline $1716 / 1717$ & 4 \\
\hline 1717 & 4,5 \\
\hline
\end{tabular}

${ }^{110}$ Fransız tüccarlarıyla 1121 (1709/1710) yılında 25 adet kalyon demiri için pazarlık yapılmış ve bunlara 13,181 kuruş ücret ödenmişti. (bk. BOA.MAD.d.2485.77.)

${ }^{111}$ Yusuf Alperen Aydin, age., s. 283. ve BOA.MAD.d.10360.47, BOA.MAD.d.10425.81, BOA.MAD.d.10359.40, BOA.MAD.d.2883.40, BOA.MAD.d.9989.45., BOA.MAD.d.3168.66., BOA.MAD.d.10354.39., BOA.MAD.d.10326.54., $\quad$ BOA.MAD.d.10313.42., $\quad$ BOA.MAD.d.10412.119., BOA.MAD.d.2864.33.

\section{ULUSLARARASI EĞİTIIM VE TARİH ARAŞTIRMALARI DERGİSİ \\ (ETA JOURNAL)}




\begin{tabular}{|l|l|}
\hline 1721 & 5 \\
\hline 1129 & 4,5 \\
\hline 1135 & 5 \\
\hline 1145 & 5 \\
\hline $1755 / 1756$ & 5 \\
\hline $1757 / 1758$ & 4,3 \\
\hline $1762 / 1763$ & 5,5 \\
\hline 1763 & 5 \\
\hline 1165 & 4 \\
\hline 1175 & 5,5 \\
\hline 1201 & 4,3 \\
\hline $1785 / 1786$ & 2,2 \\
\hline $1796 / 1797$ & \\
\hline
\end{tabular}

Tablo 3. Yı1lar İtibarıyla Kantar Başına Ödenen Ücretler.

Tablodan anlaşıldığı kadarıyla, ham demirin her bir kantarı için ödenen ücretler, 18. yüzyılın başlarından 18. yüzyıl sonlarına kadar, sadece 1 kuruşluk azalış ya da artış göstermiştir. Ham demirin elde edildiği Samakov, Sofya, Filipe, Usturumca ya da Eğridere kazalarında emek, hammadde ve üretim araçlarının değerini birbiriyle eşleştiren bu tablo, devletin miri mubayaa rejimi politikasından kaynaklanmaktayd. Bu rejimde amaç, en düşük bedelle en yüksek yararı sağlayacak mal ve hizmetleri satın almaktır. Dolayısıyla devlet bu iş için seferber edeceği mali kaynakları mümkün olduğu kadar kontrol altında tutmaya çalışmış ve bütçede önemli bir gelir kalemi haline getirmemeye uğraşmıştır. $\mathrm{Bu}$ politika donanma gemilerinin diğer inşa ve teçhiz malzemeleri olan kereste, yelken bezi, urgan, zift, katran, reçine ve üstüpüde de uygulanmıştır. Yüzyıllardan beri sürdürülen bu politikayı 18.yüzyılda zorunlu kılan bazı pratik nedenler vardır ki, bunların başında, 18. yüzyılda Rusya, Venedik ve Avusturya ile sonu gelmez savaşların ikliminde, kapıkulu ordusunun büyümesi sonucunda önceliğin bu ordunun askerlerine para yetiştirme ve savaşları finanse etmeye kaymış olması gelmektedir. Ancak ücret ve fiyatların yüz yıllık bir dönem boyunca belli bir seviyede sabitlenmiş olması üretici açısından olumsuz etkiler doğurmuştur. Hızlı fiyat artışı, yüksek enflasyon, paranın değer kaybetmesi ve devletin içine düştüğü iktisadi ve siyasi istikrarsızlıklar 
üreticinin gelir düzeyini düşürerek devletçe sabitlenen fiyatlar sebebiyle vergi yükünü ağırlaştırarak zararına üretim yapmasına neden olmuştur.

\section{2. Kömür Ücreti}

Kömür ücreti ocaklık yükümlüsü reayadan ziyade, tersanelerde demiri işleyerek malzeme imal eden işçi ve ustalara ödenmektedir. Farklı tersanelere gönderilen ham demirden; çivi, kolye ve benzeri demir aletlerin imali için demirciler tarafindan kömüre ihtiyaç duyulmaktaydı. Kömür serbest piyasada koşullarında oluşan rayiç fiyat üzerinden tüccar ya da esnaftan satın alınmaktaydı. Kömürün ücreti, demirci ücretinin içine katılmıştı. Örneğin 1791/1792 yılında, Gemlik tersanesinde inşa edilecek olan bir adet kalyon için, 24,000 vukıyye (30,768 kg.) kömür satın alınmıştı. Bu kömürün ücreti, demircilerin bizzat kendileri tarafından ödenmişti. Bu kömüre, işçiler tarafından ödenen ücret onların ücretine alacak olarak dâhil edilmekteydi. Ancak hammadde ve üretim araçlarının değerinin emeğin değeri karşısında daha hızlı biçimde büyüdüğü dönemlerde, bu durum demirciler arasında hoşnutsuzluğa sebep olmaktaydı. Çünkü serbest piyasadan temin edilen kömürün fiyatı yükselince, demircilerin ücreti reel olarak küçülmüş ve 30 kadar demirci Gemlik tersanesinden firar etmişti. Bunun sebebi sorulduğunda ise, bu iş için görevlendirilmiş olan, Dergâh-1 Âli Kapıcıbaşılarından es-Seyyid Hüseyin Bey tarafindan demircilere ödenen her 100 para ücretin, 40 parasının kömür ücreti olduğu cevabı verilmiştitin ${ }^{112} \mathrm{Bu}$ durum 18 . yüzyılda hammadde fiyatlarının emek fiyatları karşısında oldukça değer kazanmış olduğunu göstermektedir.

Kömür ücretine ilave olarak, ondan daha küçük bir miktarda olmak üzere demircilere bir de "harkü'n-nar" olarak isimlendirilen bir ücret ödenmekteydi. Bu kavram galip ihtimal eriyen demirin aktığı, insan yapısı yatağı ifade etmekteydi ve daha çok emekle ilgili bir ücretti. Bu ücret daha çok "livre" üzerinden hesaplanmaktayd1. 1791/1792 yılında Tersane-i Âmire'de çalışan demirci esnafinın kömür bahası ve "harkü'n-nar", ücretleri 1000 akçe 10 livreydi. Bu 10 livre ise "harkü'n-nar" ücretiydi. Çivi üreten demircilerin ise ücreti 330 akçe olup buna ilave olarak onlara 33 livre kadar da "harkü'nnar" ücreti ödenmekteydi ${ }^{113}$.

\section{3. Araba Ücreti}

Araba ücreti, demir satın alınan kazalardan iskelelere kadar ham demiri taşımak için tutulan arabalara ödenen ücreti ifade etmekteydi. Bu ücret de miri mubayaa rejimine tabiydi. Bu rejime göre satın alınan ham demirler, çamus ve öküz arabalarıyla belli iskelelere taşınmaktaydı. Araba temin edilen kazaların başında Dimetoka, Cisr-i Ergene, Cisr-i Mustafa Paşa ve Çirmen gelmekteydi. Samakov'dan alınan demirin iskelelere ulaştırılması için kiralanan arabaların ücretini Samakov nazırı ödemekteydi ${ }^{114} .1$ Temmuz 1784 tarihinde Samakocuk’tan alınan 5000 kantar (282,040 kg. ) ham demiri İnöz’e

\footnotetext{
112 BOA.C.BH.32.1544.1.1.

113 BOA.C.BH.32.1544.1.1.

114 BOA.MAD.d.9848.9.
}

ULUSLARARASI EĞİTIIM VE TARİH ARAŞTIRMALARI DERGİSİ (ETA JOURNAL) 


\section{$\underline{\text { Mehmet TAS }}$}

taşımak için nakliye ücreti olarak her bir kantarı 80 akçeden 400,000 akçe ücret ödenmişti ${ }^{115}$. Benzer bir uygulamaya kurşun temininde de tesadüf edilmektedir. Buna göre Sirde-Kapsi'deki kurşun madeninden çıkarılan madenler mekkari beygirleri ve arabalarla Selanik'e taşınmakta, bunların ücretleri ise Sidre-Kapsi madeni mukataası mallarından sahiplerine ödenmektedir ${ }^{116}$.

Aşağıda yıllar itibarıyla araba sahiplerine ödenen ücretler verilmiştir ${ }^{117}$;

\begin{tabular}{|l|l|}
\hline Y1llar & Akçe Cinsinden Ödenen Araba Ücreti \\
\hline 1696 & 37 \\
\hline 1703 & 65 \\
\hline $1716 / 1717$ & 80 \\
\hline 1129 & 80 \\
\hline 1135 & 80 \\
\hline 1145 & 80 \\
\hline $1755 / 1756$ & 80 \\
\hline $1772 / 1773$ & 80 \\
\hline $1783 / 1784$ & 80 \\
\hline 1201 & 120 \\
\hline $1786 / 1787$ & 80 \\
\hline 1210 & 80 \\
\hline
\end{tabular}

Tablo 4. Y1llar İtibarıla Kiralanan Arabalara Ödenen Ücret.

Samakov ve civarından 1704 yılı ile 1770 yılları arasında Tekirdağ iskelesine taşınan ham demir için araba ücreti olarak kantar başına sabitlenmiş bir ücret olan 80 akçe ödenmiştir. İstisnai bir durum olarak 1716 senesinde 100 akçe ödenmişti ki bunun sebebi ham demirin kış mevsiminde çekilmesi sebebiyle işin zorluğuna binaen ahalinin zam talebi üzerine kantar başına 20 akçe zam yapılmış olmasıydı. Sonraki senelerde yine

115 BOA.MAD.d.4375.92.

116 Sidre-Kapsi, maden hasılatından elde edilen 2000 kantar $(112,816$ kg.) kurşunun 1000 kantarının $(56,320 \mathrm{~kg}$.), Niş kalesine geri kalan 1000 kantarının (56,320 kg.) ise İstanbul'a gönderilmesi hakkında 12 Ramazan 1151 (23 Ocak 1739) tarihinde maden eminine hitaben yazılan ferman için bk. BOA.MAD.d.3864.26.

${ }^{117}$ BOA.MAD.d.4375.92.,BOA.MAD.d.2925.94.,BOA.MAD.d.10359.40.,BOA.MAD.d.10326.54,

BOA.MAD.d.10313.42., BOA.MAD.d.10412.119., BOA.MAD.d.10425.80., BOA.MAD.d.2864.33.

\section{ULUSLARARASI EĞİTIM VE TARİH ARAŞTIRMALARI DERGİSİ \\ (ETA JOURNAL)}


kantar başına 80 akçe ödenmeye devam edilmiştir ${ }^{118}$. Bu ödemenin reel değerini korumak ve nakliyatın ağır bir angarya halini almasını önlemek için arabacılardan bac, hamaliye, gümrük, harç-1 kantariye ve iskele vergisi adıyla herhangi bir ücret alınmasını yasaklamışt ${ }^{119}$. Bunun için Edirne kadısına, Edirne bostancıbaşısına, Edirne gümrük eminine ve yol üzerindeki kadı ve voyvodalara hitaben fermanlar gönderilmiştir ${ }^{120}$.

Edirne konumu itibarıyla demir nakliyatında önemli bir ara istasyon işlevi görmekteydi. Hem kara yoluyla hem de nehir yoluyla buraya taşınan demirler buradan arabalarla Tekirdağı iskelesine nakledilmekeydi. Filipe'den Edirne'ye gelen demirin bir kısmı Meriç nehri vasıtasıyla ve sallar kullanılarak taşınmaktaydı. Edirne-Tekirdağ arası mekkari arabalarıyla 20 saatlik bir mesafeye sahipti. Bu mesafede demir taşıyan mekkari arabalarına uzun süre araba başına 50 akçe ödenmiştir ${ }^{121}$.

18. yüzyılda temel tüketim maddelerinin fiyatları, piyasaların istikrarsızlığı ve iktisadi krizlerin etkisiyle birkaç kat birden artarken ham demir üreticilerine ve nakliyecilerine ödenen ücretin hemen hemen aynı kalması miri mubayaa rejiminden kaynaklanmaktadır. $\mathrm{Bu}$ rejim gereği üreticiye verilen ücret üreticinin kullandığı hammadde ve sarf etmiş olduğu emeğinin gerçek karşılığı değildi. İtibari bir karşılığıydı. Miri mübayaa rejimiyle üreticiye ödenen ücretin yükselmesi üretici açısından kazancın artması anlamına gelirken devlet açısından ham demiri temin maliyetinin artması anlamına gelmekteydi. Devletin ve reayanın çıkarı bu rejimde çok az kesişmekteydi. Farklı bir bakış açısıyla devlet donanma için malzeme sağlama işini biraz da reayasına sağladığı güvenlik hizmetinin karşılığı ve bazı vergilerden muafiyetin bir sonucu olarak görerek bunun reayasıyla kendisi arasinda bir ticaret konusu haline gelmesini istemiyordu. Esasinda bu usul ahalinin avarız benzeri mali yükümlülüklerine karşılık olarak devlet tarafindan ahaliye sunulmuş bir seçenektir. Ocaklık kazalarda yaşamayan demir üreticilerinin devlete bu şekilde ham demir satma yükümlülügü yoktur. Devletin askeri nitelikli mal ve hizmetlere duyduğu ihtiyaç, 18. yüzyılın ikinci yarısında askeri zorunluluklar nedeniyle hızla arttığ zaman devletin gelirleri aynı oranda artmadığı için miri mubayaa rejimi de daha yoğun bir şekilde işletilmiştir. Pamuklu bez, iplik, kereste, demir, zift, kendir vb. askeri ihtiyaca cevap veren malzemeleri üreten ve bunların ticaretini yapanlar üzerine bu yolla yeni yükler getirilmiştir ${ }^{122}$.

\section{4. Navlun Ücreti}

Navlun, denizcilik literatüründe bir yerden bir yere ulaştırılmak için gemiye alınan eşyaların tümünü ifade ettiği gibi taşınacak yük için gemi kaptanı tarafından yük

\footnotetext{
118 Yusuf Alperen Aydın, age. , s. 284.

${ }^{119} \mathrm{Bu}$ ücretlerin isim isim sayılmış olması arabacılardan bunları talep eden taşra yöneticilerinin olduğu ihtimalini akla getirmektedir. Konuyla ilgili ferman için bk. BOA.MAD.d.10384.42.

120 “...zikr olunan demir Tekfurdağı'na gelince nüzul eylediği mahallerde gümrük ve bac ve kantariye akçesi mübaya'a mübaşirinin tayin eylediği adamları ve arabacıları rencide ettirilmemek üzere Edirne kadısı ve bostancıbaşı ve yol üzerinde vaki kadılar ve voyvodalara ve Edirne gümrük eminine hitaben emr-i şerif verildi. (29 Cemaziyülevvel 1143)" (bk. BOA.MAD.d.10323.33.)

${ }^{121}$ BOA.MAD.d.10354.40.

${ }^{122}$ Mehmet Taş, age., s. 143.
}

\section{ULUSLARARASI EĞİTIIM VE TARİH ARAŞTIRMALARI DERGİSİ} (ETA JOURNAL) 
sahibinden istenen ücreti de ifade etmektedir ${ }^{123}$. Konu bağlamında navlun bu ikinci anlamında kullanılmıştır. Ham demir temininde navlun ücreti önemli bir yer tutmaktaydı. Çünkü ham demirin İstanbul'a ulaşması için kara yoluyla birlikte deniz yolu da kullanılmaktaydı. Ham demirler, yük arabalarıyla deniz kıyısındaki Varna, Kavala, Tekirdağ1 ve Selanik gibi iskelelere taşınmakta buradan ise hamallar vasıtasıyla gemilere yüklenerek İstanbul'a ve diğer tersanelere sevk edilmekteydi. Gemi kiralama görevi adı geçen kazalardaki gümrük eminlerine aitti. 1771/1772 y1lında Kara Biga iskelesinde inşa edilecek 4 adet pergende için gerekli olan 800 kantar $(45,126$ kg.) demirin Tekirdağ 1 gümrük emini tarafından kiralanacak gemilerle gönderilmesi emredilmişti ${ }^{124}$. Gümrük eminlerinin navlun için ödemiş olduğu ücret ise, onların devlete olan mukataa borçlarına mahsup olmaktayd1. Gümrük eminleri, demir nakli için kiraladıkları gemileri ayrı bir lonca halinde örgütlenmiş olduğu anlaşılan gemi reisleri loncası vasıtasıyla temin etmekteydi ${ }^{125}$. Bu konuda onun muhatabı adı geçen loncanın kethüdasıydı. Gerek ham demir ücreti olsun gerekse kömür, araba ve navlun ücreti olsun bütün ücretlerin peşin ve nakit ödenmesi esast ${ }^{126}$. Bu uygulama üreticinin lehine olan ve onu kamu görevlilerinin keyfi kararlarından koruyan bir uygulamadır.

\section{5. Ücretleri Karşılamak İçin Kullanılan Mali Kaynaklar}

Ham demir satın alıp belli iskeleler üzerinden deniz yolunu da kullanarak İstanbul'a taşımak yüksek ücretler gerektiren bir işti. $\mathrm{Bu}$ iş için üreticilere, ham demire, araba kiralarına, hamallara ve navlun ücreti olarak gemi kaptanlarına yüklü miktarda paraların ödenmesi gerekiyordu. Devlet bu yüzden ortaya çıkan yüksek maliyeti tek bir vergi kaynağı ya da kuruma yüklemek yerine onu bunlar arasında paylaştırmayı tercih etmiştir. Böylece hem vergi kaynağı kurutulmamış hem de donanmanın inşa ve teçhizi son derece önemli olan bir konuda tek bir gelir kaynağına bağlı kalmanın riskleri en aza indirilmiştir. Masrafların bölüştürüldüğü gelir ve kurumların başında İstanbul cizyesi gelirleri, Selanik gümrüğ̈̈ gelirleri, Samakov nazırlığı gelirleri ve çeşitli kazaların mukataa gelirleri gelmektedir.

\section{1. İstanbul Cizyesi}

Cizye kelimesi, "kâfi gelmek, karşılığını vermek, ödemek" anlamına gelen ceza mastarından türetilmiş bir isim olup İslam devletlerinde gayri müslim tebaanın devlete ödemiş olduğu vergiyi isimlendirmek için kullanılmıştır. Bu vergi, gayrimüslim ahaliden harbi statüsündeki kişilerden ayrı tutulmaları ve devlet tarafindan can ve mal güvenliklerinin sağlanması karşılığı olarak tahsil edilmektedir. Bu vergiyi tahsil etmekle görevli olan kişiye ise cizyedar denilmektedir. İslam hukukunda, cizye gayri müslim

\footnotetext{
${ }^{123}$ Metin Karayazgan, age. , s. 97.

${ }^{124}$ Kara Biga ayanı Hacı Emirzade tarafından Kara Biga iskelesinde inşa olunacak 4 adet pergende için Tekirdağı gümrükçüsüne hitaben yazılan ferman için bk. BOA.MAD.d.10386.67.

125 İneada iskelesinden İstanbul'a nakledilecek olan demirler için 19 Zilkade 1206 (9 Temmuz 1792) tarihinde İstanbul gümrük emini Hasan ağaya reisler kethüdası marifetiyle bir tane gemi kiralaması emredilmişti. (bk. BOA.MAD.d.10422.59.

${ }^{126}$ BOA.MAD.d.10354.38.
} 


\section{YÜZYIL OSMANLI DONANMASI İĊIN HAM DEMIR TEMINİ}

tebaa ile yapılan zimmet anlaşmasına göre alınır. Haniflere göre, İslam devletinde bir yıldan fazla ikamet eden müstemen statüsündeki kişilerden de alınmaktadır ${ }^{127}$.

Ham demir temininde İstanbul cizyesi gelirleri zaman zaman maksadın tahakkuku için seferber edilmiştir. Örneğin Sinop iskelesinde inşa olunacak 10 adet kalyon için Samakov, Tatarpazarı, Filipe ve Sofya kazalarından satın alınacak ham demir için gerekli olan 28,333 kuruş tutarındaki ücret, Mart 1756 tarihinde İstanbul Cizyedarı Abdurrahman tarafından ödenmiştir. O, ilgili kişilere hem satın alınan ham demirin ücretini hem de bunların iskelelere nakli için gerekli olan araba ücretlerini ödemiştir ${ }^{128}$.

Rodos adası cizye gelirlerinin de ham demirin temininde kullanıldığı anlaşılmaktadır. Rodos adasında kalyon inşasına memur edilen Kızılhisarzade Mir Ahmet'e 20 Ağustos 1759 tarihinde gönderilen hükümde inşa edilecek kalyonlarda kullanılmak üzere 500 kantar $(28,204 \mathrm{~kg})$ ham demirin ücreti olan 2500 kuruşun 1759/1760 senesi Rodos cizyesi malından havale olunması emredilmiştir ${ }^{129}$.

\section{2. Selanik Gümrüğü}

Gümrük, devletlerarası ticarette sınır geçişleri sırasında malların kontrol edildiği yerdir. Bu geçiş sırasında tüccarlardan alınan vergiye gümrük resmi ya da gümrük vergisi adı verilmektedir. Osmanlı gümrükleri sahil gümrükleri ve kara gümrükleri olarak ikiye ayrılmaktaydı. Kara gümrükleri genelde iç ticarete konu olan mallara uygulanırken sahil gümrükleri hem iç hem de diş ticarete konu olan mallara uygulanmaktaydı. Selânik, İstanbul, İzmir, Antalya, Beyrut, Trabzon ve Kefe gibi sahil limanları yalnız dış ticaret için değil deniz ulaşımının kolay ve daha ucuz olması münasebetiyle iç ticaret için de önemli limanlard $1^{130}$. Buralarda alınması gereken gümrük vergilerini gümrük eminleri tahsil etmekteydi. Onlar, devlet adına bu işi ya emanet usulüyle ya da iltizam usulüyle gerçekleştirmekteydi.

Balkan kazalarından toplanan ham demirin, önemli sevk merkezlerinden birisi olan Selanik gümrüğü, demir masraflarını karşılayan kurumlardan bir tanesiydi. Selanik'in coğrafi konumu dolayısıyla iç ve dış ticarette gelişmiş bir liman şehri olması, tüccarlar için burasını önemli bir kavşak haline getirmişti. Bu husus şehrin gümrük gelirlerini artırmıştı. 22 Kasım 1762 tarihinde Bender-Süveyş tersanesinde inşa olunacak 2 adet kalyon için Kavala, Pravişte, Zihne, Serez, Usturumca, Eğridere ve Demirhisar kazalarından vukıyyesi 3 paraya olmak üzere 2000 kantar $(112,816 \mathrm{~kg})$ ham demir satın alınması emredildiğinde bu miktar ham demirin ücretinin Selanik gümrük emini Osman tarafindan ödenmesi emredilmiştir ${ }^{131}$.

\section{3. Samakov Nazirlığı}

${ }^{127}$ Mehmet Erkal, "Cizye”, TDV İslam Ansiklopedisi, Cilt 8, İstanbul 1993, s. 42.

128 BOA.MAD.d.10359.40.

${ }^{129}$ BOA.C.BH.240.11149.1.1.

${ }^{130}$ Mübahat S. Kütükoğlu, “Gümrük”, TDV İslam Ansiklopedisi, Cilt 14, İstanbul 1996, s. 263.

${ }^{131}$ Konuyla ilgili olarak, Selanik mollasına, Kavala, Pravişte, Zihne, Serez, Demirhisar, Usturumca ve Eğri Dere kazalarının kadı ve naiplerine, Selanik mütesellimi Ali ve Selanik Gümrük Emini Osman’a ve vilayet ayanları ile iş erlerine hitaben 5 Cemaziyülevvel 1176 (22 Kasım 1762) tarihinde gönderilen hüküm için bk. BOA.MAD.d.9989.117.

\section{ULUSLARARASI EĞİTIIM VE TARİH ARAŞTIRMALARI DERGİSİ} (ETA JOURNAL) 
Osmanlılarda maliye, idare ve vakıf kurumlarına yönetici veya denetleyici olarak atanan kimseye nâzır denirken ilgili kurum ve faaliyete de nezaret denilmiştir. Bu anlamının dışında devletin askeri konularda ihtiyaç duyduğu her türlü malzemenin imali, top dökümü, bina ve gemi yapımı, tamiri veya sökülmesi gibi işleri sonuçlandırmak üzere geçici nitelikte yapılan görevlendirmeleri anlatmak için de genellikle bu terim kullanılmıştır. Ayrıca birçok kurum veya faaliyetin yönetilmesi yahut sadece kurallara uygunluğunun denetlenmesiyle ilgili görevlilere de nâzır denmiştir. Bu yüzden devlet içinde nâzır unvanlı görevler büyük çeşitlilik göstermiştir ${ }^{132}$.

Samakov demir madeni mukataası gelirleri, Samakov nazırı tarafından yönetilmekte ve bu mukataanın gelirleri zaman zaman donanmanın ham demir ihtiyaçlarını karşılamak için seferber edilmektedir. Bu uygulama 17. yüzyılda da mevcut olan bir uygulamayd. Örneğin 28 Ağustos 1666 tarihinde Samakov kadısına gönderilen bir hükümde, Samakov'dan 1000 kantar $(56,4320 \mathrm{~kg})$ ham demir satın alınıp Tersane-i Âmire'ye gönderilmesi ve bu iş için Samakov nazırından 64,000 akçe alınarak kiralanacak arabalara sarf olunması emredilmiştir ${ }^{133}$.

\section{4. Mukataa Gelirleri}

Kesmek anlamına gelen Arapça kat' kökünden türeyen mukataa teriminin, belirli bir miktar üzerinde karşılıklı olarak anlaşmak anlamına gelen genel bir anlamı vardır. Osmanlılar bu terimle devlete ait bazı vergilerin belirli bir meblağ karşılığında iltizama verilmesi anlamını kast etmişlerdir. Bu terim 19. yüzyılın ortalarına kadar olan sürede anlam olarak genişleyerek hazineye ait bir kısım vergilerden oluşturulmuş birer malî birim anlamını kazanmıştır. 18. yüzyılda mukataa uygulaması epey yaygınlık kazanmıştır. Osmanlı Devleti'nde mukataalar geniş bir çeşitlilik göstermekteydi. Madencilikte özellikle altın ve gümüş madenlerinin hemen tamamı ile bakır ve kurşun madenlerinin en büyük bölümü, şap madenleriyle tuzlaların tamamı, ziraatta pirinç ekimine gerekli alt yapı tesisleri devlete ait olduğu gibi esnaf imalâtının az çok önemli fizikî sermaye gerektiren boya ve basma atölyeleri, mum imalâthaneleri, kahve değirmenleri vb. alanlarda pek çok kuruluşun başlıca sahibi devlet olduğu için bütün bu kuruluşların hemen tamamı birer mukataa olarak örgütlenmiş bulunuyordu ${ }^{134}$.

Karahisar-1 Şarki ve Amasya mukataalarının malları ham demir masraflarını karşılamak için seferber edilen mallard1. 28 Şubat 1777 tarihinde Sinop’ta inşa edilecek 2 adet kalyon için yeterli miktarda ham demir temin etmek için Karahisar-1 Şarki ve Amasya kazası mukataaları mallarından 10,000 kuruşun havale edilerek bu iş için görevlendirilmiş olan kapıcıbaşıya verilmesi emredilmişti ${ }^{135}$.

\section{Ham Demir Temininde Karşılaşılan Sorunlar ve Çözüm Arayışları}

\footnotetext{
132 Mehmet Genç, "Nazır”, TDV İslam Ansiklopedisi, Cilt 32, İstanbul 2006, s. 449.

${ }^{133}$ Konuyla ilgili Tersane Emini Süleyman'ın, Edirne'den İstanbul'a göndermiş olduğu mektup üzerine, yapılacak iş ve işlemleri anlatan 26 Safer 1077 (28 Ağustos 1666) tarihli hüküm için bk. BOA.MAD.d.9848.9.

${ }^{134}$ Mehmet Genç, "Mukataa”, TDV İslam Ansiklopedisi, Cilt 31, İstanbul 2006, s. 129-130.

135 BOA.MAD.d.10392.62.
} 
Donanmanın ihtiyaç duyduğu ham demirin temini konusu sorunsuz bir düzlemde ilerlememiştir. Merkezi yönetim, iklim koşulları, piyasa koşulları ve taşra kaynaklı birçok sorunun ortasında bu konu kendi mecrasında yol almıştır. 18. yüzyılın tanık olduğu dış ve iç kaynaklı birçok sorun kendini bu alanda da hissettirmiş ancak devlet bu sorunları aşarak temin sistemini işletmeye çalışmıştır. Yaşanan sorunlar bu yüzyılda sadece donanma lojistiği konusunda olmayıp devlet yönetimi, eğitim sistemi, toprak yönetimi, askeri sistem ve taşra yönetimi de içinde birçok sorunu kapsamaktayd1. Ham demir temininde yaşanan sorunların başında ise ham demirin ilgili yerlerden zamanında toplanamaması, kamu görevlilerinin usulsüzlük ve yolsuzlukları ile üretim maliyetlerinde yaşanan beklenmedik yüksek fiyat artışları gelmekteydi.

\section{1. Ham Demirin İlgili Yerlerden Zamanında Toplanamaması}

Ocaklık usul ile Tersane-i Âmire ve diğer tersanelere ham demir sağlayan kazalardan ham demirin zamanında toplanamaması, önemli bir sorun teşkil etmekteydi. Demirin toplandıktan sonra Tersane-i Âmire bünyesindeki Mahzen-i Sürb'e depo edilmesi gerekmekteydi. Derya mevsimi olarak isimlendirilen mart ve kasım ayı arasında geçen altı aylık sürede ham demirin İstanbul dışındaki tersanelere ulaştırılması icap etmekteydi ${ }^{136}$. Ancak bu her zaman mümkün olmamaktaydı. Çünkü, ilgili kazalardan zamanında toplanamayan demir, Mahzen-i Sürb’te demir açı̆̆ı sorunu yaşanmasına ve farklı tersanelerde oluşan talebin burası tarafından karşılanamamasına neden olmaktaydı. $\mathrm{Bu}$ sorunun temelinde ise ham demir üreticilerinin miri mubayaa rejimine göre devlete mal satmayı, zararına yapılan bir iş olarak görmeleri sonucunda ellerindeki ham demiri daha yüksek fiyat teklif eden tüccara sattıkları için devlete satacak ham demirlerinin kalmayışı veya bulundukları yerden sosyal ve iktisadi nedenlerle göç etmeleri ya da demir üretimi yerine tarım ve hayvancılık gibi diğer iktisadi faaliyetlere yönelmeleri yatmaktaydi.

Önemine göre bu nedenler arasında bir sıralama yapmak gerekirse, serbest piyasa koşullarında faaliyet gösteren yerli ve yabancı tüccarların ocaklık ham demir üreticilerinin elindeki ham demiri daha yüksek fiyata satın alması bu nedenlerin başında gelmekteydi. Örneğin, Bender-Süveyş tersanesinde inşa olunacak 2 adet kalyon için Kavala, Pravişte, Zihne, Serez, Demirhisar, Usturumca ve Eğridere havalisinden 2000 kantar $(112,816$ kg.) ham demir satın alınması gerektiği zaman Çuhadar Halil isimli mübaşir bu iş için görevlendirilmiş ancak aynı mübaşir adı geçen kazalardan bu miktar ham demiri toplamanın mümkün olmadığını ve Nefs-i Selanik’teki tüccarlardan bu demirin satın alınması emr olunursa 5-10 gün zarfında bunu temin edeceğini 22 Kasım 1762 tarihinde bildirmişti ${ }^{137}$. Devlet bu durumda serbest çalışan demir tüccarlarından

\footnotetext{
136 Sinop tersanesinde inşa olunan kalyonlar için gerekli olan ham demir 21 Muharrem 1201 (13 Kasım 1786) yılında derya mevsimi olmadığ 1 için Mahzen-i Sürb’ten yollanamamış bu ise kalyonlarda "ahen-i hamın eşed lüzumunu” beraberinde getirmişti.(bk. BOA.MAD.d.2925.94.)

137 “....kat'i cevap verdiği ve kazalara memur olan mübaşirlerden husul haberi henüz varid olmamağla Nefs-i Selanik'te olan tüccardan mübaya'ası ferman olunur ise beş on gün zarfinda mubaya'a ve tahsili mümkün olacağını çuhadar-1 merkum, memhur mektubunda...” (bk. BOA.MAD.d.9989.117.)
} 
ihtiyacı olan demiri satın almaya yönelmekte ancak bu da işin maliyetinin yükselmesine neden olmaktaydi.

Ham demirin zamanında Mahzen-i Sürb'te depolanamaması, Tersane-i Âmire kadar İstanbul dişındaki diğer tersaneler için de ciddi bir sorundu ${ }^{138}$. Tersane-i Âmire bir vücuda devamlı kan pompalayan bir kalp misali diğer tersanelere malzeme ve iş gücü göndermekte ve bu tersanelerin normal faaliyetlerini sürdürmesini sağlamaktaydı. Bu yüzden Mahzen-i Sürb’te demir bulunamadığında bu durum sadece Tersane-i Âmire içindeki gemi inşa faaliyetlerini değil imparatorluğun birçok yerine dağılmış bulunan diğer tersanelerin de faaliyetlerini etkiliyordu. 18. yüzyılda zaman zaman yaşanan bu sorun varlığını 19. yüzyılın başına kadar sürdürmüştü. 1802/1803 yılında Tersane-i Âmire'de inşa olunan bir adet üç ambarlı ve bir adet normal büyüklükte bir kalyon ile bir adet korvete gerekli olan çivi ve kolye için 1000 kantar $(56,320 \mathrm{~kg}$.) ham demire ihtiyaç duyulduğunda bu miktar demirin Mahzen-i Sürb’te olmadığ 1 anlaşılmışt1 ${ }^{139}$. Bu durumlarda başvurulan en pratik çözüm yolu, genellikle tersane eminine burgucubaş1 vasitasıyla Galata'da mevcut olan ham demiri kayıt ettirip ücreti karşılığında tüccardan satın almasının emredilmesi olmuştur ${ }^{140}$. Ham demirin Tersane-i Âmire'de yeterince bulunmaması halinde başvurulan ikinci bir yol ise Cebehane-i Âmire gibi diğer kamu kurumlarından bu ihtiyacın karşılanmasıyd $1^{141}$.

Ham demir kadar yokluğu hissedilen diğer bir unsur ise meselenin iş gücü boyutunu oluşturan demircilerdi. 18. yüzyılda tüccar kalyonlarının inşasını desteklemek devlet politikası halini alınca demirci ustaları kendilerine devletten daha yüksek teklif eden tüccarların kalyon inşa faaliyetinde çalışmaya yöneldiler. Devletin tüccar kalyonlarının inşasını desteklemesinin nedeni ise bu kalyonların savaş kalyonların dönüştürülebilmesi ve Venedik korsanlarına karşı tüccarların kendilerini bu kalyonlarla Akdeniz'de daha kolay savunabileceğine inanmasıydı. Demirci açısından kamu sektörü ile özel sektör arasında emek ücretleri konusundaki makas açıldıkça onlar için tüccar kalyonlarında çalışmak daha çekici hale gelmekteydi. Bu durum ise kamu sektöründe demirci iş gücü açığına neden oldu. Devlet bunun önünü almak için emeğin ücretine zam yapmak yerine belli tersanelerde inşası süren devlet kalyonlarının inşası bitmeden demircilerin tüccar kalyonlarında çalışmasını yasaklayan yasal önlemlere başvurmayı tercih etti. 21 Ekim 1771 tarihinde yayınlanan bir fermanda tüccarlara ait üç direkli şayka ve sandal inşasında demircilerin istihdam olunmaları nedeniyle devlete ait iki adet kalyonun inşasının

\footnotetext{
138 "Saha-i Tersane-i Âmire'de derdest inşa olan üç ambarlı kalyon el-haletü hezihi sektirme gelüb külli yevm otuz kırk kantar (2256 kg.) mismar ve sair mamulat-1 âheniyeye sarf olunmak hasebiyle Mahzen-i Sürb'te mevcut demir-i ham kalmayub külliyatlı demire muhtaç olduğu ma'lum-1 devletleri buyuruldukta dahi ne mahalden irade buyuruluyor ise bin kantar $(56,408 \mathrm{~kg}$.) demir-i ham i'tası babında emr ü ferman devletli inayetli sultanım hazretlerinindir."(bk. BOA.C.BH.146.7017.1001.)

${ }^{139}$ BOA.C.BH.104.5006.1.1.

140 “ Sa'adetlü atıfetlü Tersane-i Amire emini efendi hazretleri.burgucubaşı ma'rifetiyle Galata'da mevcut demir-ham var ise tahrir ittirdilüb ve bahasını kat' ittirdüb i'lama himmet buyuralar."(bk. BOA.C.BH.146.7017.1001)

${ }^{141}$ Tersane-i Âmire'de inşa edilen iki adet pergende için yeterli miktarda demirin, Mahzen-i Sürb’te bulunmadığı anlaşılınca Cebehane-i Âmire'den 500 kantar (28,204 kg.) demirin 7 Rebiyülahir 1186 (8 Temmuz 1772) tarihinde verilmesi emredilmiştir. (bk. BOA.C.BH.250.11564.1.)
} 
geciktiğinden bahsedilmekte ve Kastamonu sancağı mütesellimine gerekli uyarılar yapilmaktayd $1{ }^{142}$.

\section{2. Kamu Görevlilerinin Usulsüzlük ve Yolsuzlukları}

Merkez ve taşradaki kamu görevlilerinin usulsüzlük ve yolsuzlukları, ham demir temininde karşılaşılan sorunlardan birisiydi. $\mathrm{Bu}$ görevlilerin başında, merkezi yönetim için tayin edilmiş mübaşir, Mahzen-i Sürb emini ve kâtipleri ile taşrada görev yapan mütesellim ve subaşılar gelmekteydi. Reayanın en çok şikâyet ettiği kişi ise mübaşirdi. Mübaşirlerden bazıları, devlet için demir satın alındıktan sonra tekrar ocaklık demiri üreticilerinden devlet adına demir satın almakta ve bunu daha sonra piyasa fiyatı üzerinden serbest piyasada satmaktaydı. Devletin narh fiyatı ile serbest piyasada arz ve talep dengesine göre oluşan rayiç fiyat arasındaki fark onun kârıydı. Ham demirin piyasadan bu şekilde çekilerek belli ellerde toplanması en çok nalburcu ve demirci esnafinı mağdur etmekteydi. Çünkü hammadde talebinin yükselmesiyle birlikte ham demirin piyasa fiyatı da yükselmekte bu ise demirci esnafının üretim maliyetini artırmaktaydı. Mübaşirlerin bu yolsuzlukları, uzun süre demirci esnafının şikâyetine konu olmaya devam etti. Devlet ise bu durumda şikâyetçilerin bulunduğu kazanın kadısına hüküm göndererek yeni bir ferman gönderilmeden, ahaliden tekrar ham demir satın alınmasının önlenmesini emretmekteydi. Bu konuda bir örnek, Rusçuk’ta yaşanmıştı. Rusçuk kazasında yaşayan demirciler, Edirne'den İstanbul'a bir arzuhal göndererek devlet adına ham demir satın mübaşiri şikâyet etmişlerdi. İddialarına göre, bu işe memur edilen mübaşir 500 kantar $(28,204 \mathrm{~kg}$. ) ham demiri devlet adına satın aldıktan sonra "celb-i mal" sevdasıyla kazaya gelen demire devlet adına el koymuş daha sonra da bu demiri daha fazla fiyatla piyasada satmak istemişti ${ }^{143}$. Kamu görevlilerinin en fazla şikâyete konu olan eylemlerinden bir diğeri de demirin naklinde araba sürücülerinden bac, hamaliye, gümrük vergisi, kantariye ve gemi ücreti gibi yasa dışı keyfi ücretler talep etmeleriydi ${ }^{144}$.Bunlar taşra üzerinde merkezi kontrolün zayıflaması yani padişah otoritesinin güç kaybetmesinin sonuçlarıyd ${ }^{145}$.

İstanbul dışındaki Kemer, Bodrum ve Sinop gibi tersanelerde kalyon inşası için görevlendirilmiş olan görevlilerin gemilerin inşası konusunda merkezi yönetimi bilgilendirmemesi ayrı bir sorun kaynağıydı. Bu sorun taşra tersanelerinde kalyon masraflarının kontrolsüz biçimde artarak merkezi bütçeden yapılan harcamalar

\footnotetext{
142 BOA.MAD.d.10386.72

${ }^{143}$ BOA.MAD.d.9848.7.

${ }^{144}$ Konuyla ilgili 20 zilkade 1165 tarihli ferman için bk.BOA.MAD.d.10354.

145 Padişahın şahsında temayüz eden merkezi otoritenin zayıflamasına en canlı örneklerden birisini III.Selim (1789-1807) Osmanlı-Rus-Avusturya savaşı (1787-1792) münasebetiyle serdar-1 ekremlerden birine göndermiş olduğu hatt-1 hümayunda görmek mümkündür. Padişah serdar-1 ekreme gönderdiği hatt-1 hümayunda;

“...maazallah bu beta'et hasebiyle yarın düşman yürüdüklerinde sen ve ricalden kim, benim elimden kurtulur? Bunu mülahaza etmiyorsun. Ferman yazmaktan da gayri bir tedbir yok...Ferman gönderildikte ardı aranıp icra olunmamanın sebebi kimdir? Tashih ve siyaset etmek iktiza etmez mi?...Alimallahü te'ala sizlerin bu misüllü hareketlerinden bana hayret ve istırap geldi." (bk. Enver Ziya Karal, III.Selim'in Hatt-1 Hümayunlar1, Türk Tarih Kurumu Basımevi,Ankara,1942, s.153.)
}

\section{ULUSLARARASI EĞİTIIM VE TARİH ARAŞTIRMALARI DERGİSI \\ (ETA JOURNAL)}

INTERNATIONAL JOURNAL OF EDUCATION AND HISTORY RESEARCH

Yıl: 4, Sayı: 1, Ocak 2022, s.24-67. 
konusunda merkezi yönetimin denetim imkanının kaybolması riskine neden olmaktaydı. Tersane-i Âmire bünyesinde yer alan Mahzen-i Sürb’ten gönderilen demirin yetmemesi üzerine yeniden gönderiliyor ancak gemilerin inşası yine de bitmiyordu. $\mathrm{Bu}$ ise merkezi yönetimin kalyon inşası için memur edilen görevlilerin dürüstlüğü hakkında onlardan şüphe duymasına neden olmaktaydı. 5 Mart 1792 tarihinde çıkarılan bir fermanda Kemer tersanesinde 45 ziraa (34 m.) uzunluğunda bir firkateyn inşası için Hacı Emirzade el-Hac Mehmet'in görevlendirilmiş olduğundan bahisle kendisine birkaç kez 15,000 kuruşa varan para ile 500 kantara $(28,204 \mathrm{~kg})$ kadar ham demir gönderilmiş olmasına rağmen geminin bitirilememiş olmasından duyulan rahatsızlık ifade ediliyor ve rehavet ya da gevşeklikten dolayı gemi inşası bitirilememişse cezalandırılmakla tehdit ediliyordu ${ }^{146}$.

Konuyla ilgili başka bir örnek 18.yüzyıl ortalarında yaşanmıştı. Dubniçe kazasındaki demirciler 1752/1753 y1lında mahkemeye başvurarak öteden beri devlete verdikleri demirin Samakov mahkemesinde tevzi edildiğini ancak son 1-2 seneden beri bu kurala riayet edilmediği için üretim güçlerinin üzerinde demir üretmeye zorlandıklarını ve bu sebeple kazaları içinde, sadece 4-5 demir işletmesinin kaldığından bahsetmişlerdi. Mahkemeden eski usule dönülmesi için yeniden ferman çıkarılması için İstanbul'a başvurulmasını istemişlerdi. Anlattıklarına göre mevcut halde kendilerinden istenen demiri üretmeye güçleri yetmediği için devlete karşı büyük bir borca duçar olmuşlar, demir işletmeleri harap olmuştu ${ }^{147}$. Onların şikayetlerinde bahsi geçen eski tevzi ve taksim usulünün bozulmasının sebebi yine kamu görevlileriydi. Çünkü Dubniçe'de yaşayanları ve onların ödeme gücünü en iyi bilerek en doğru taksimatı yapacak olan mahkemeydi. Dubniçe'de yaşarken göç eden ya da ölenlerin bilgisi mahkeme kayıtlarına işlenmekte iken buna merkez ya da taşradaki kamu görevlilerinin dikkat etmemesi ve aynı miktar demiri geride kalan demir üreticilerinden talep etmesi ister istemez mevcut vergi yükünün iyice ağırlaşmasına neden olmaktaydı.

Mahzen-i Sürb, ham demirin depolanıp sarf olunduğu yer olması dolayısıyla konu bağlamında ayrı bir önemi haizdi. Buradan sarf edilen ham demirin kaydı ve çıkışı ile ilgili düzenlemelere riayet edilmemesi yapılan sarfiyatın denetimini zorlaştırmaktaydı. Bunda, Mahzen-i Sürb eminlerinin liyakatsiz kişilerden seçilmesi ve kâtipler dâhil bazı çalışanların birbiri ile yakın akraba olması onların kapalı devre çalışan bir sistem kurmasına ve çeşitli yolsuzlukların yaşanmasına neden olmuştur. 15 Nisan 1713 tarihinde yayınlanan bir fermanda, Mahzen-i Sürb'te sarf olunan demir ve diğer malzemelerin sayı ve cinsiyle tartılması ve liman reisi tezkiresi ile sarf olunması, amele ücretlerinin ise liman reisi vasitasıla zapt ve defter ettirilmesi hususu İstanbul kaymakamına, kaptanıderyaya ve tersane eminine emredilmişti. Fermanın gerekçesi, Tersane-i Âmire ve Karadeniz tersanelerinde inşa edilmekte olan kalyonlara sarf olunan kereste ve demire ait ücret ve diğer masrafların gereği gibi kayıt edilmemiş olmasıydı ${ }^{148}$. Kayıtlar düzenli

\footnotetext{
${ }^{146}$ Kemer sahasında kalyon inşasına memur olan Hacı Emirzade el-Hac Mehmet'e 11 Recep 1206 (5 Mart 1792) tarihinde gönderilen konuyla ilgili fermanın detayları için bk. BOA.C.BH.30.1434.1.1.

${ }^{147}$ Dubnice kazası ahalisinin talebiyle ilgili 23 Cemaziyülevvel 1166 (28 Mart 1753) tarihli ferman için bk. BOA.MAD.d.10354.38.

${ }^{148}$ BOA.MAD.d.2883.42.
} 
tutulmadığı zaman, demirle ilgili yapılan masraf ve harcamaları takip etmek zorlaşıyor bu ise hem kamu görevlilerinin yeni usulsüzlüklerine kapı aralıyor hem de daha fazla kamu kaynağının bu işe tahsis edilmesine neden oluyordu.

Taşradaki kamu görevlilerinden olan mütesellimlerin ise zaman zaman demircileri kendi vergi mükellefleri olarak görerek onları kalyon inşasının gerçekleştirildiği tersanelere göndermedikleri anlaşılmaktadır. Devlete iltizam sözleşmesiyle belli bir meblağ ödeyerek mütesellimlik görevini üslenmiş olan bu kişilerin vergi mükelleflerinden devlete ait vergileri tahsil ederek yapmış oldukları masrafı çıkarmak isteyecekleri aşikârdı. Onların bu tutumu ise kalyon inşasında gecikmeye sebebiyet verdiği için merkezi yönetim tarafından hoş karşılanmamıştır. Böyle bir örneğe 5 Mayıs 1757 tarihinde tesadüf edilmektedir. Bu tarihte Rodos iskelesinde el-Hac Ali tarafından 2 adet kalyon inşa edilecekken bu iş için Rodos adasındaki demircilerden bir kısmı da seferber edilmiştir. Ancak Rodos mütesellimi Abdullah, bu demirciler için; "Benim reayamdır." diyerek onları yakalayarak hapsetmiş bu yüzden de el-Hac Ali tarafindan İstanbul'a şikâyet edilmiştir. Kendisi “tamah-ı ham” sahibi olmakla itham edilerek tedip olunması için hakkında ferman çıkarılmıştır ${ }^{149}$.

\section{3. Üretim Girdilerinde Yaşanan Yüksek Fiyat Artışlanı}

Emek ve girdi maliyetlerinde yaşanan beklenmedik fiyat artışları, demir üreticilerini zor durumda bırakmış ve üreticilerin istenen miktarda demiri zamanında devlete teslim edememelerine neden olmuştur. Örneğin 1761/1762 y1lında Sofya, Samakov, Tatarpazarı ve çevresinden satın alınan ocaklık demirin her bir Samakov kantarına devletçe 5 kuruş takdir edilirken üreticiler; odun, demir cevheri ve gümrük ücretlerinin yükselmesini gerekçe göstererek ve uzak mesafelerden demiri temin etmelerini de bahane ederek imal ettikleri demirin her bir Samakov kantarına 2 kuruş zam yapılarak 7 kuruş ücret talep etmişlerdir. Ancak bu fiyat artışlarını gerçekçi bulmayan devlet onların ücret artışı taleplerini reddetmiştir ${ }^{150}$.

Aşırı fiyat artışlarının etkisini hissettirdiği tek malzeme ham demir değildi. Yelken bezinde de bu sorun yaşanmaktaydı. Donanmaya yelken bezi, ocaklık yoluyla Boğazhisarları ve çevresinden ya da Tersane-i Âmire içinde 18. yüzyılda açılan Bezhane'den temin edilmekteydi. 1710/1711 tarihinde Galatalı dokumacilardan olan Yelkenci İsmail Efendi, Bezhane için Edremit ve Boğazhisarı bölgesinden 35,896 kilogram pamuk ipliğini her bir vukıyyesi 48 akçeden satın almayı kendi rızasıyla üslenmiştir. Bu kişi miktarı belirtilmiş olan ipliği satın alarak Bezhane'ye teslim etmeyi taahhüt etmiştir. Ancak 21,794 kilogram pamuk ipliğini Bezhane'ye teslim ettikten sonra geri kalan ipliklerin teslimatını durdurmuştur. Kendisine bunun sebebi sorulup ipliğin geri kalan iplik kendisinden talep edildiğinde ise 48 akçe ücret ile istenen miktarda ipliği

\footnotetext{
${ }^{149}$ BOA.MAD.d.10359.50.

${ }^{150}$ Tatarpazarı naibi ve dergâh-1 âli gediklilerinden olup Samakov tarafina ham demir satın almaya memur edilmiş Yusuf'a 17 Rebiyülevvel 1176 (6 Ekim 1762) tarihinde gönderilen konuyla ilgili hüküm için bk. BOA.MAD.d.9989.40.
}

\section{ULUSLARARASI EĞITIM VE TARIH ARAŞTIRMALARI DERGISİ}

(ETA JOURNAL)

INTERNATIONAL JOURNAL OF EDUCATION AND HISTORY RESEARCH

Yıl: 4, Sayı: 1, Ocak 2022, s.24-67. 
satın almasının mümkün olmadığını daha yüksek bir ücret ile bu işin yapılabileceğini bildirmiştir ${ }^{151}$.

Üretim girdilerinde ve temel tüketim maddelerinde 18. yüzyılda yaşanan beklenmedik fiyat artışları, tersanelerde çalışan marangoz, kalafatçı ve burgucu ile diğer işçilerin ücretlerinde reel olarak gerilemeye neden olduğu anlaşılmaktadır. Aldıkları ücret nominal olarak aynı kalmasına rağmen yüksek enflasyon koşullarında işçi ücretlerinde yaşanan reel gerileme onların hayat standardının gerilemesine ve dolaysıyla şikayetlerine neden olmaktaydı. 1770/1771 yılında Tersane-i Âmire içinde çalışan işçiler, Tersane-i Âmire dışında aynı koşullarda çalışan işçilere 20 para ücret verildiğini, kendilerine ise yevmiye olarak 10 para ücret verildiğini, geçindirmekle yükümlü oldukları, aile ve evlatları olduğunu, fakir bulunduklarını, kendilerine verilen 10 para ücretlerine bir miktar zam yapılmadıkça çalışmayacaklarını beyan ederek durumlarını padişaha arz etmişlerdi. $\mathrm{Bu}$ durumun gemi inşa faaliyetine zarar vereceği anlaşıllnca yevmiyelerine 2 para zam yapılmasına karar verilmişti ${ }^{152}$. Hiç şüphe yok ki üretim girdilerinde yaşanan artış demir üreticilerinin muhalefetini daha çok körüklüyordu. Üreticiler bu durumda kendilerinden demir talep edildiğinde bunu vermemek için çeşitli bahaneler ileri sürmekteydiler. Örneğin 1776/1777 yılında Drama kazası ahalisi kazalarında demir olmadığını bildirmiş, komşu kaza olan Kavala kazası ahalisi ise kazalarının “cezire ve sengistan” olduğu gerekçesiyle kendilerinden talep edilen 57 kantar demiri teslime yanaşmamışlardi ${ }^{153}$.

18.yüzyılda fiyat artışları farklı ürünlerde farklı düzeylerde seyretmiştir. Örneğin Amasya'da 18.yüzyılda temel gıda maddelerinde yaşanan fiyat artışlarını konu alan bir çalışmaya göre; 1765 yılında 10 akçe olan tuz 1770 yılında 24 akçeye, sade yağ 54 akçeden 72 akçeye, zeytin yağı 72 akçeden 96 akçeye, katran 10 akçeden 18 akçeye, nohut 9 akçeden 12 akçeye yükselmiştir ${ }^{154}$. Stanford Shaw'ın İstanbul'u da içine alacak şekilde 1756-1800 yılları arasında bazı tüketim maddelerinin fiyatlarını göstermek için oluşturduğu bir fiyat listesi, bu dönemde mal fiyatlarında yaşanan artışlar hakkında fikir verici veriler içermektedir. Buna göre 1756 'da toz şeker 20 para iken 1800'de 120 paraya, pirinç 1756 'da 6 para iken $1800^{\prime}$ de 28 paraya, sabun 1756 'da 13 para iken 1800 'de 36 paraya, sıvı yağ 1756 'da 12 para iken 1800 'de 32 paraya, tereyağ 1756 'da 12 para iken 1800 'de 50 paraya yükselmiştir ${ }^{155}$. Temel tüketim maddesi olan bu ürünler, demir üretiminde kullanılan her türlü insan ürünü olan emeğin daimî girdilerini oluşturmaktadır.

18. yüzyılda düşman devletlere karşı kara ve denizde yapılan sürekli savaşlar, Avrupa'da silah teknolojisinde yaşanan değişime karşılık vermek için kapıkulu ordusu personelinin artırılması ve her padişah değişikliğinde verilmesi neredeyse kanun haline gelmiş olan cülus bahşişleri devletin nakit paraya olan ihtiyacını artırmıştır. Sarayın

\footnotetext{
${ }^{151}$ Mehmet Taş, age., s. 170.

152 Tersane-i Âmire Emini el-Hac Yusuf Efendi’nin konuyla ilgili ilamı üzerine 29 Rebiyülevvel 1184 (23 Temmuz 1770) tarihinde gönderilen ferman hakkında bk. BOA.MAD.d.10386.67.

${ }^{153}$ BOA.MAD.d.10392.59.

154 Yılmaz Karadeniz, Amasya'da Fiyatlar, OTAM (Ankara Üniversitesi, Osmanlı Tarihi Araştırma ve Uygulama Merkezi Dergisi,), Cilt 11,Sayı 11, Y1l 2000.

155 Mehmet Taş, age., s. 171.
} 
ihtiyaçları ile rakip devletlere ödenen savaş tazminatları bu ihtiyacı iyice acil hale getirmiştir. Devlet ise bu ihtiyacı gidermek için kamu gelirlerini iltizam, mukataa ya da malikâne usulü ile satışa çıkarmıştır. Bu tedbirlere rağmen kamu maliyesinde yaşanan buhranlar ve nakit para sıkıntısı farklı tersanelerde yürütülen kalyon inşa faaliyetlerini olumsuz etkilemiştir. İşçilerin ücretleri zamanında ödenemeyince bu durum işçiler ile devleti karşı karşıya getirmiştir. Sinop tersanesinde kalyon inşasına memur edilen Ahmet Kaptan'in 2 Temmuz 1804 tarihinde bildirdiğine göre bu tersanedeki işçilerin ücretleri 6 ay ödenememiş bunun üzerine işçiler bir araya gelerek ücretleri ödenmezse hep birlikte tersaneden firar edeceklerini bildirmişlerdir ${ }^{156}$.

Üretim girdilerinde yaşanan artışta klasik Osmanlı ekonomi sisteminin Yeni Çă̆ Avrupa'sında ortaya çıkan yeni ekonomik gelişmelere uyum sağlayamaması etkili olmuştur. Yüksek enflasyon ve fiyat artışlarının en büyük nedeni arzın iç ve dış talebe yetişememesiydi. Osmanlı ekonomisi istihdam, fiyat, iç ve dış ticaret, para ve maliye politikasında klasik Türk-İslam ekonomisinin referanslarıyla hareket eden muhafazakâr bir ekonomiydi. İslam ekonomisinde eksik rekabet koşullarında fiyatlara müdahale etme gerektiği ilkesi (narh), Osmanlı ekonomi düşüncesi ve uygulamasında büyük bir yere sahipti. Tespit edilen fiyatlar sonucu, esnaf ve tüccara tanına kâr haddi \%5 ile \%15 arasında değişmekteydi. Esnaf birlikleri ise esnaf ve tüccarın işsiz kalmaması ya da aşırı üretim buhranlarının önlenmesi amacıyla "ihtiyaca göre üretim" fikrini uygulamaya çalışıyordu. Dükkân sayısı, üretim araçları ve sayısı sınırlandırılmıştı. Ekonominin bileşenlerinden olan esnaf, memurların kadro sistemine benzer gedik usulüne bağlıydı. İhtiyaç duyuldukça yeni kadrolar açılır böylece ticaret zümresinin aşırı büyümesi engellenirdi ${ }^{157}$. Esnafin birbirinin üretim ve satış sahası dışında faaliyet göstermesi yasaktı. Bunun yanı sıra Osmanlı toprak sisteminin özelliği nedeniyle Osmanlı yönetici sınıfının toprakta küçük mülkiyet hakkı korunmuş olduğu için sermaye sınıfının birikim zeminini oluşturacak bir toprak sınıfı da olmamıştır ${ }^{158}$. Böylesi otarşik bir yapının nüfusun sınırlı, arz ve talebin dengeli olduğu, üretimin düşük, komik ilişkilerin ise ülkesel ve bölgesel düzeyde seyrettiği bir ortamda Yeni Çağ' 1 kendine has kuralları ve ruhu olan ekonomileriyle rekabet etmesi mümkün değildi.

Üretim girdilerinde yaşanan beklenmedik fiyat artışlarının doğal bir sonucu kaçakçılığın yaygınlaşmasıydı. Devletin "miri fiyat" düzeyi üzerinden demir üreticisine ödediği ücretin gerçek değeri sıra dışı girdi maliyetlerindeki artış nedeniyle geriledikçe üretici kendisine daha yüksek fiyat teklif eden tüccara ürününü satmaya yönelmiştir. Tüccarın serbest piyasa koşullarında oluşan fiyat düzeyinden yaptığı teklif kendisine cazip gelmiştir.18.yüzyılda merkezi otoritede yaşanan zayıflama ise bu işi kolaylaştırmıştır. Büyük tüccarlar doğrudan demir üreticisinden almış oldukları demiri İnöz iskelesine arabalarla taşıdıktan sonra buradan gemilere yükleyerek İzmir'e nakletmiş

156 Ahmet Kaptan'ın konuyla ilgili olarak 23 Rebiyülevvel 1219 (2 Temmuz 1804) tarihinde padişaha yazdığı arzuhal için bk. BOA.C.BH.217.10126.2.1.

157 Ahmet Vecdi Can-Hakan Aliusta-Aydın Bağdat,’Osmanlılarda Muzaaf Usule Erken Geçilememesinin Ssoyo-Ekonomik Nedenleri, Gazi Akademik Bakış, Cilt 13, Sayı 25, Kış 2019, s.310-311.

158 Şahin Çetinkaya, "Kamu Kaynakları İle Özel Sermaye Sınıfının Oluşması; Türkiye Örneği”, Yalova Sosyal Bilimler Enstitüsü Dergisi, Cilt 9, Sayı 19, Ekim 2019,s.5.

\section{ULUSLARARASI EĞİTIIM VE TARİH ARAŞTIRMALARI DERGİSİ}

(ETA JOURNAL)

INTERNATIONAL JOURNAL OF EDUCATION AND HISTORY RESEARCH

Yıl: 4, Sayı: 1, Ocak 2022, s.24-67. 
ve burada daha yüksek bir fiyatla başka tüccarlara satmıştır ${ }^{159}$. Bu durum ise İstanbul'daki nalbur esnafı ile Tersane-i Âmire'deki gemi inşa faaliyetine zarar vermiştir.

\section{4. Satın Alınan Ham Demirin Kalite Olarak Düşük Olması}

Devletin askeri ihtiyaçları için ocaklık kazalardan satın alınan ham demirin belli özelliklere sahip olması gerekiyordu. En azından içindeki demir cevheri düşük olmamalı ve kullanışlı demir aletleri üretimine uygun olmalıydı. Ancak bazen satın alınan ocaklık demirin bu özellikleri yeterince taşımadığı anlaşılmaktadır. Örneğin 30 Ağustos 1777 tarihinde Pazarcık Voyvodası Ahmet ile Filipe Nazırı Ömer tarafindan Sofya'dan satın alınan ham demirin "mağşuş" ve demir araç ve gereçleri imal etmeye uygun olmadığ1 (amele gayri sâlih) anlaşılmışt1 ${ }^{160}$.

Ham demirin, "mağş̧uş" ve "amele gayri sâlih" olması olgusunun demir üreticilerine narh fiyatı üzerinden ödenen ücretin, onların ürünlerini piyasa fiyatıyla tüccara satmış olsalardı elde edecekleri ücretten daha düşük olmasıyla yakından ilgisi vardır. Çünkü ham demir üreticileri devletin kendilerine ödemiş olduğu ücretle kömür, örs, çekiç, ocak vs. üretim araçlarını almak zorunda olup bunlar için ürün piyasasına bağlıydılar. Dolayısıyla emek dâhil bu malzemelerin fiyatı çoğu zaman narh yoluyla belirlenmeyip arz-talep dengesinin geçerli olduğu piyasa koşullarına göre belirlenmekteydi. Bu malzemelerin fiyatı serbest piyasada yükselince, üreticilerin mübaşirden aldığı ücret, değer olarak küçülerek bunların ücretini karşılayamaz hale gelmekteydi. Ham demir üreticilerine ödenen ücretin, rakamsal olarak aynı kalmasına rağmen değer olarak küçülmesi onların satın alma gücünün zayıflayarak ihtiyaç duydukları malzemeleri satın alamamalarına neden olmaktaydı. Onlar da bu durum karşısında kendi çözüm yollarını bulmuşlar ve ham demirin içindeki demir filizi oranını düşürmüşlerdi. $\mathrm{Bu}$ durum donanmaya başka malzemeler sağlayan diğer üreticiler için de geçerliydi. Yelken bezi üreticileri demir üreticilerinin izlediği yolun bir benzerini bulmuşlardı. Örneğin 1780/1781 tarihinde Tersane-i Âmire'ye alınacak mayistra türü yelken bezinin her bir topu 1,4 kg. , alborta türü yelken bezinin ise $1,06 \mathrm{~kg}$. ağırlı̆ğında olması kararlaştırılmışken numuneleriyle kıyaslandığında mayistra bezinin $0,39 \mathrm{~kg}$. ve albortanın ise $0,7 \mathrm{~kg}$. ağırlığında olduğu görülmüştür. Üretilen bez neredeyse $1 / 3$ oranında daha hafiftir. Satın alınan yelken bezleri hiç olmazsa iki sene kullanılmaya uygunken bu eksik ağırlıktaki bezler bir seneden fazla kullanılamamaktaydı. Mevcut durumu hem devlet hem de üretici açısından sürdürülebilmek zorlaşmıştı. Buna rağmen 18. yüzyıl boyunca bu durum, ham demir ve yelken bezi temini için kurulan sistemde ciddi bir zafiyete neden olmadi ${ }^{161}$.

\footnotetext{
${ }^{159}$ Konuyla ilgili Evahir Recep 1167 (Nisan/Mayıs 1754) tarihli ferman için bk. BOA.MAD.d.10356.59.

${ }^{160}$ BOA.C.BH.30.1418.1.1.

${ }^{161}$ Mehmet Taş, age., s. 175.
} 
Donanma malzemelerinin kalitesindeki düşüş aynı dönemde Fransız donanmasında da görülmekteydi.18.yüzyıl boyunca kereste, kendir ve topların birçok teslimatı kötü kaliteli kabul edilerek tersanelerin rıhtımlarında reddedilmiştir ${ }^{162}$. Kalite kavramının gelişimi donanma ile onun ekonomik ortakların eşit şekilde yer aldığı kolektif bir çabanın ürünüydü ${ }^{163}$.

\section{5. Olumsuz Hava Koşulları ve Deniz Kazaları}

Farklı kazalardan satın alınan ham demirin gemilerle İstanbul'a taşınırken bazen olumsuz hava koşulları nedeniyle denizde batması ya da karaya oturması ham demirin zamanında Tersane-i Âmire'ye ulaşmasını engelliyordu. Çok sık olmasa da zaman zaman bu sorun yaşanıyordu. Örneğin Delvine sancağından satın alınması emredilen 4,000 kantar $(225,280 \mathrm{~kg})$ demir, 1774/1775 yılında Selanik iskelesine taşındıktan sonra buradaki mahzenlerde depolanmıştı. Buradan İstanbul'a taşınması gerekirken Akdeniz'deki olumsuz hava koşulları nedeniyle bunların nakli uygun bir zamana ertelenmek zorunda kalınmıştı ${ }^{164}$. Ancak bu durum sadece demire ya da Akdeniz'e has bir durum değildi. Başka donanma malzemelerinin temininde başka denizlerde de bu durum yaşanmaktayd1. 1739/1740 yılında Karadeniz seferi dönüşünde devlete ait gemilerden 2 parça kancabaş, 3 parça firkate ve 1 parça işkampoyeden oluşan bir filo, Balaklava'da batmış içinden çıkarılabilen eşyalar ise Balaklava Dizdarı Ali'ye teslim olunmuştur. Aslında bu tür kazalar dünyanın diğer yerlerinde de meydana gelmekteydi. Örneğin İspanya-Amerika arasında 1546-1650 yılları arasında toplam olarak 14,456 sefer yapan geminin 402'si olumsuz hava koşulları sebebiyle batmıştı. Yine 1717 yılları arasında 2221 sefer gerçekleştiren gemilerden $85^{\prime}$ i batmışt ${ }^{165}$. Elde mukayese için yeterli sayısal veri olmasa da Atlas okyanusuna kıyasla iklim olaylarında Karadeniz'in daha fazla belirsizlik ve kararsızlık içermesi nedeniyle orantısal olarak burada daha fazla deniz kazasının meydana geldiği aşikardır.

Osmanlı denizleri içinde özellikle Karadeniz, bu tip deniz kazalarının yoğunlaştığı bir denizdi. Burada esen şiddetli rüzgâr gemilerin yelken ve direklerini kırarak onların batmas1 ya da karaya oturmasina neden olmaktayd. Devlet bu durumda, kaza mahallindeki kazaların yerel yöneticilerine gemideki malzemelerin bir şekilde çıkarılarak İstanbul'a gönderilmesini emretmekteydi. Örneğin 1785/1786 yıllarında Tersane-i Âmire için Hacı Velizade el-Hac Süleyman tarafindan temin edilen malzemeler gemi ile İstanbul'a taşınırken Kefken civarında şiddetli rüzgâra yakalanmış ve geminin direkleri kırılınca karaya oturmuştu. Gemide bulunan malzemelerin başka bir gemiye yüklenerek İstanbul'a ulaştırılması için Kefken, Enez ve Midye havalisindeki kadılara ve kadı naiplerine hitaben ferman çıkarılmıştı. İstanbul'a gönderilmesi emredilen malzemeler arasında 14 kantar (789 kg.) ağırlığında ham demir de bulunmaktayd ${ }^{166}$.

\footnotetext{
${ }^{162}$ David Plouviez, “The French Navy And War Entrepreneurs: İdentity,Business Relations, Conflict And Cooperation İn The Eighteenth Century, Business History,60:1, 2018,s.46.

${ }^{163}$ David Plouviez, agm. s. 48.

${ }^{164}$ BOA.MAD.d.10384.42.

${ }^{165}$ Carlo M.Cipalla, Fatihler, Korsanlar, Tüccarlar, Tarih Vakfi Yayınları, İstanbul, 2003, s. 14.

166 BOA.MAD.d.2925.90.
}

ULUSLARARASI EĞİTIIM VE TARİH ARAŞTIRMALARI DERGİSI

(ETA JOURNAL)

INTERNATIONAL JOURNAL OF EDUCATION AND HISTORY RESEARCH

Yıl: 4, Sayı: 1, Ocak 2022, s.24-67. 


\section{Sorunları Ortadan Kaldırmak İçin Alınan Önlemler}

Ham demir temininde yaşanan sorunları devletin iktisadi, ticari ve sosyal temelleri olan çok yönlü bir bakış açısıyla ele aldığını iddia etmek mümkün değildir. Genelde sorunlar güvenlikçi bir bakış açısıyla asayiş sorunu derecesine indirgenmiş ve polisiye önlemlerle başa çıkılmaya çalışılmıştır. Şüphesiz, kamu görevlilerinin usulsüzlüklerinde olduğu gibi polisiye önlemler alınmasını gerektiren sorunlar bulunmakla beraber meselenin uluslararası ve iç piyasadan kaynaklanan boyutları daha ağır basmaktadır. Bu konuda alınan tedbirlerden birisi Tersane-i Âmire tarafindan istenen ham demiri imal etmeye yarayacak funda kömürünün Tersane-i Âmire ihtiyacı karşılanıncaya kadar tüccara satılmasının yasaklanmasıdır ${ }^{167}$. Gelenekselcilik ve iaşecilik gibi ilkelerin geçerli olduğu Osmanlı iktisadi pratiklerine uygun olan bu yasağın tamamen uygulanabildiğini ileri sürmek yaşanan sorunlar bağlamında pek de mümkün değildir.

Meseleyi devlet ve reaya arasındaki hak ve sorumluluklar çerçevesinde gören bir anlayışın sonucu olarak devletçe gerekli tedbirler alınırken gerek kamu görevlileri olsun gerekse reaya olsun onların meseleyi ilgilendiren davranışlarına odaklanılmış ve onları olumsuz davranışlara iten geri plandaki nedenler genelde göz ardı edilmiştir. Çıkarılan ferman ve hükümlerde kamu görevlileri ve reaya sıklıkla: “...tehavün ve müsamaha ve tekasül ve müsahaleden ihtiraz-ı azim eyleyesin..." “...firkateyn-i mezburun tekmiline

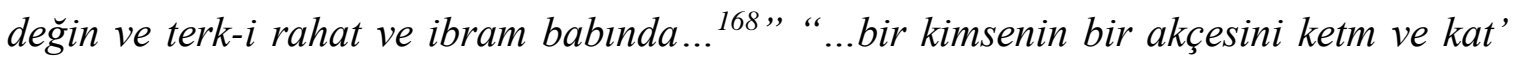
olunmayıb...169", “...şer'an tedibi iktiza edenler olursa tayin olunan kalyon kaptanı marifetiyle te'dib olunub ta'til-i maslahat-ı mühimmeye bais olur harekete bir ferde ruhsat gösterilmemek... ${ }^{170 ”, ~ “ . . . n i z a m-l ~ m u b a y a a y a ~ k a t ' a ~ h a l e l ~ g e l m e m e k ~ v e ~ h i c ̧ b i r ~}$ ferde gadr ve himaye olunmamak ve ta'dil ve tesviyeye riayet olunmak... ${ }^{171}$ " şeklindeki genel ve soyut ifadelerle uyarılmışlardır. Bununla birlikte bu yüzden cezalandırılan ya da görevinden uzaklaştırılan merkezi ya da yerel kamu görevlilerine dair çalışma bağlamında bir bilgiye rastlanmamıştır. Bu durum devletin izlediği güvenlikçi yaklaşımı, ham demir temininde tam bir başarıyla uygulayamadı̆̆ını da göstermektedir. Bu durumun 18. yüzyılda merkezi otoritede yaşanan zayıflama ve taşrada ortaya çıkmaya başlayan ayan gibi feodal yapılarla yakından ilişkisi vardır.

\footnotetext{
${ }^{167}$ BOA.MAD.d.10350.54.

${ }^{168}$ BOA.C.BH.30.1434.1.1.

169 BOA.MAD.d.9989.40.

${ }^{170}$ BOA.MAD.d.9989.122.

${ }^{171}$ BOA.MAD.d.9989.31.
} 


\section{YÜZYIL OSMANLI DONANMASI İĊIN HAM DEMIR TEMINİ}

\section{Sonuç}

1645-1669 Osmanl1-Venedik savaşında, Osmanlı donanması kalyon teknolojisini etkili biçimde kullanan Venedik donanması karşısında başarısız olunca devlet ricali kalyon teknolojisine geçişi tartışmaya başlamıştır. $\mathrm{Bu}$ tartışma 1701 yılında yayınlanan Bahriye Kanunnamesi ile kalyon lehine kesin biçimde sona ermiştir. Köken olarak denizcilik mesleğinden gelen Kaptanıderya Mezemorto Hüseyin Paşa bu kanunnamenin mimarı iken ondan sonra gelen Kaptanıderya Canım Hoca Mehmet Paşa, adı geçen kanunname ile birlikte kurulan yeni düzenin istikrar kazanmasına büyük hizmetlerde bulunmuştur. $\mathrm{Bu}$ sebeple, Osmanlı Devleti'nin kalyon teknolojisine geçişi birbirini tamamlayan kaptanıderyaların yönetimi altında devam eden uzun bir sürecin sonucu olup onun arka planında siyasi ve askeri zorunluluklar yatar.

Osmanlı Devleti'nin kalyon teknolojisine geçişi, beraberinde idari ve lojistik olarak yeni bir teşkilatlanma ihtiyacını getirmiştir. Dolayısıyla 18. yüzyılda Liman Reisliği ve Bezhane gibi kurumlar vücuda getirilmiştir. Kalyonların kadırga ve diğer savaş gemilerine kıyasla daha büyük ve daha geniş olması daha fazla kereste, yelken bezi, zift, katran, reçine ve kendir ihtiyacının doğmasına neden olmuştur. Ham demir ihtiyacı da buna paralel olarak büyümüştür. Ham demirin kalyon inşasında özellikle çivi, kolye, lenger vb. malzemelerin imalatında kullanılması bunların ise kalyonlar için hayati öneme sahip olması onu önemli bir malzeme haline getirmiştir. Ham demir ihtiyacının büyümesi ocaklık usulüyle devlete ham demir sağlayan üreticilerin yükünü artırmıştır. Uzun ve sık yaşanan savaşlar ikliminde bu ihtiyacın daha çok artması beraberinde birtakım sorunların yaşanması gerçeğini de getirmiştir. Bütün bunlara rağmen ham demir konusunda Osmanlı Devleti kendine özgü bir temin sistemi meydana getirerek dişa bağımlı olmadan gemilerinin demir ihtiyacını karşılamayı başarmıştır.

$\mathrm{Bu}$ konuda devletin büyük ölçüde kendi yerli kaynaklarına dayandığını ileri sürmek, rahatlıkla mümkündür. Devletin dışa bağımlı kalmak yerine kendi öz kaynaklarına dayanması hem devlete hem de donanmaya rakiplerine karşı daha bağımsız hareket etme imkânı vermiştir. Ancak daha sonra ortaya çıkan Sanayi İnkılabı ve beraberinde gelen Buharlı Gemiler çağı ile birlikte, vapurun kalyonların yerini alması bu alandaki yerleşik düzenin sarsılmasına neden olmuştur. Çünkü buhar teknolojisi Osmanlı Devleti'nin yabancısı olduğu bir teknoloji olup bu teknolojiyi ülke içinde üretecek nitelikli iş gücü ve bilgi birikimi dönemin koşulları içerisinde Osmanlı ülkesinde mevcut değildir. Bu olumsuz durum, inşa ve donatım yönünden donanmanın rakiplerinden bağımsız hareket etme imkanını kaybetmesine ve dışa bağımlı hale gelmesine neden olmuştur. Bu yüzden donanmanın 18.yüzyıl sonu ile 19. yüzyıl başından itibaren rakiplerine karşı etkisini yitirmeye başlamasının sebebini ihtiyaç duyduğu malzemeleri sağlamak için kurmuş olduğu temin sistemindeki aksamalardan ziyade Avrupa'da gemi inşası konusunda yaşanan bilimsel gelişmelerde aramak daha isabetli olacaktır.

\section{ULUSLARARASI EĞİTIM VE TARİH ARAŞTIRMALARI DERGİSi}

(ETA JOURNAL)

INTERNATIONAL JOURNAL OF EDUCATION AND HISTORY RESEARCH

Yıl: 4, Sayı: 1, Ocak 2022, s.24-67. 
Donanmanın lojistik ve donatımı dahil olmak üzere gerek 18.yüzyılda yaşanan gelişmeler, gerekse ondan sonraki 19. yüzyıl yapılan çalışmalar bundan sonra yapılacak olan faaliyetlerde karar vericiler için yol gösterici olmuştur. Bir binanın duvarı gibi üst üste binen tuğlalar misali her bir ders ve bu dersten edinilen her bir tecrübe sorunların çözümünde sonraki dönemin devlet yöneticileri için adeta pusula işlevi görmüştür. $\mathrm{Bu}$ yüzden bu alanda yaşanan hiçbir değişim tarihin tozlu sayfalarında kaybolup gitmiş gerçekler değildir.

Netice olarak denebilir ki, Osmanlı Devleti 18. yüzyıl boyunca ham demir temini konusunda, emek, sermaye, üretim araçları, ulaşım araçları ve üretim konusunda bütün bileşenleri bir şekilde bir arada tutarak yönetmeyi başarmıştır. Sistemin aksayan ya da topallayan bütün yönlerine rağmen 18. yüzyıl boyunca Osmanlı donanmasının demir ihtiyacını karşılama konusunda sistemi içeriden sarsan ciddi bir tehditle karşılaşmaması bunu kanıtlamaktadır. Bu durum temin sisteminin gücü ve sağlamlığı hakkında araştırmacılara fikir verici bir mahiyet taşımaktadır.

\section{KAYNAKÇA}

\section{A.Osmanlı Arşiv Belgeleri}

Cevdet Bahriye (C.BH.):20.967, 25.1184, 30.1434, 30.1438, 32.1544, 36.1712, 41.1933, 51.2417, 91.4397, 104.5006, 146.7017, 217.10126, 240.11149, 247.11461, 250.11564 .

Cevdet Hariciye (C.HR.):25.1227.

Cevdet Maliye (C.ML.):549.22594.

Maliyeden Müdevver Defterler (MAD.d.): 2485.61, 2485.73, 2485.74, 2485.80, 2489.27, 2864.33, 2883.40, 2883.42, 2925.84, 2925.90, 2925.94, 3014.65, 3014.73, $3014.83,3133.37,3168.74,3168.79,3419.197,3435.17,3864.26,4375.92,6266.76$, 9848.7, 9848.9, 9848.21, 9848.22, 9848.63, 9989.26, 9989.40, 9989.45, 9989.60, 9989.102, 9989.117, 10321.53, 10323.33, 10326.54, 10336.52, 10350.54, 10350.61, 10354.13 , 10354.38, 10354.39, 10354.40, 10354.41, 10357.50, 10356.59, 10359.40, $10359.46,10359.50,10359.53,10360.47,10384.42,10386.67,10386.72,10386.80$, $10388.70,10391.83,10392.62,10392.59$, 10412.104, 10413.111, 10412.119, $10413.121,10418.2,10413.125,10415.90,10425.81,10427.60,10429.73$.

Sadaret Divan Kalemi Defterleri:(A.DVNS.MHM.):103.12, 103.27.

B.Araştırma ve İnceleme Eserler

ALTI, Aziz - BAŞKUTLU, Salih, "Bebek Peksimethanesi”, Osmanlı Mirası Araştırmaları Dergisi, 7/18, 2020, s. 419-437.

AYDIN, Yusuf Alperen, Sultanın Kalyonları, Küre Yayınları, İstanbul 2011.

BOSTAN, İdris, Osmanlı Bahriye Teşkilatı, 17.Yüzyılda Tersane-i Âmire, Türk Tarih Kurumu, Ankara 2003. 
CAN, Ahmet, Vecdi - ALİUSTA, Hakan - BAĞDAT, "Aydın Osmanlılarda Muzaaf Usule Erken Geçilememesinin Sosyo-Ekonomik Nedenleri”, Gazi Akademik Bakış, Cilt 13, Sayı 25, Kış 2019.

CIPALLA Carlo M., Fatihler, Korsanlar, Tüccarlar, Tarih Vakfi Yayınları,İstanbul,2003.

ÇETINKAYA Şahin, "Kamu Kaynakları İle Özel Sermaye Sınıfının Oluşması; Türkiye Örneği”, Yalova Sosyal Bilimler Enstitüsü Dergisi,Cilt 9,Sayı 19, Ekim 2019,s.5.isi,),Cilt 11,Say1 11, 2000.

ERKAL, Mehmet, "Cizye”, TDV İslam Ansiklopedisi, Cilt 8, İstanbul 1993.

GENÇ, Mehmet, "Nazır”, TDV İslam Ansiklopedisi, Cilt 32, İstanbul 2006.

GENÇ, Mehmet, "Mukataa”, TDV İslam Ansiklopedisi, Cilt 31, İstanbul 2006.

GÖKTEPE, Kaya, “Osmanlı Döneminde Tekirdağ'da yapılan Hayvancılığın İstanbulun İaşesi İle Sanayi ve Ticari Faaliyetlerindeki Rolü”, Trakya Üniversitesi,Sosyal Bilimler Dergisi, Sayı 1, Cilt 20,Haziran 2018.

HINZ, Walter, İslam'da Ölçü Sistemleri, Çeviren: Acer Sevim, Edebiyat Fakültesi Basımevi, İstanbul, 1990.

İŞBİLİR, Ömer, "Savaş ve Bölgesel Ekonomi:İran savaşlarında Doğu Karadeniz ve Doğu Anadolu”, OTAM (Ankara Üniversitesi,Osmanlı Tarihi Araştırma ve Uygulama Merkezi Dergisi), Cilt 2007, Say1 21,2007.

KARADENIZ, Yılmaz, “Amasya'da Fiyatlar”, OTAM (Ankara Üniversitesi,Osmanlı Tarihi Araştırma ve Uygulama Merkezi Dergisi, Cilt 11,Sayı 11, Y11 2000.

KARAL Enver Ziya,III.Selim'in Hatt-ı Hümayunları,Türk Tarih Kurumu Basımevi,Ankara,1942.

KARAYAZGAN, Metin, Denizci Sözlüğü, Karşıyaka, 1981.

KATİP ÇELEBİ, Tufetü’l- Kibar fi Esfari'l-Bihar, Hazırlayan: Orhan Şaik Gökyay, Kervan Kitapçılık, Cilt 2., İstanbul 1980.

KİEL, Machiel, "Samakov", TDV İslam Ansiklopedisi, Cilt 36, İstanbul 2009.

KÜTÜKOĞLU, Mübahat S. , "Gümrük", TDV İslam Ansiklopedisi, Cilt 14, İstanbul,1996.

ORAL, Kutlay, "Demir Cevherinin Metalurjisinin Doğuşu ve Tekâmülü”, Bilimsel Madencilik Dergisi, Sayı 6, Y11 1970.

PAKALIN Mehmet Zeki, Osmanlı Tarih Deyimleri ve Terimleri Sözlüğüu, Cilt 1-2, 3.Bask1, Milli Eğitim Basımevi, İstanbul 1983.

QUATAERT, Donald, Osmanlı İmparatorluğu 1700-1922, Çeviren:Ayşe Berktay, İletişim yayınları,3.Baskı, İstanbul,2004. 
PLOUVIEZ, David, “ The French Navy And War Entrepreneurs: İdentity,Business Relations, Conflict And Cooperation İn The Eighteenth Century, Business History, 60:1, 2018.

ŞAHİN, Güven, “Türkiye Zirai Hayatında Manda (Bubalus Bubalis) Yetiştiriciliği ve Manda Ürünlerinin Değerlendirilmesi”, İstanbul Üniversitesi Edebiyat Fakültesi Coğrafya Dergisi, Sayı 31, İstanbul 2015.

TAŞ, Mehmet, 18.Yüzyılda Osmanlı Donanmasında Yelken ve Yelken Bezi, Basılmamış Doktora Tezi, Kahramanmaraş 2019. 